NBER WORKING PAPER SERIES

\title{
THE IMPACT OF EDUCATION ON HEALTH AND HEALTH BEHAVIOR IN A MIDDLE-INCOME, LOW-EDUCATION COUNTRY
}

\author{
Resul Cesur \\ Bahadir Dursun \\ Naci Mocan \\ Working Paper 20764 \\ http://www.nber.org/papers/w20764 \\ NATIONAL BUREAU OF ECONOMIC RESEARCH \\ 1050 Massachusetts Avenue \\ Cambridge, MA 02138 \\ December 2014
}

We thank Rexford Santerre, Jorge Agüero, Padmaja Ayyagari, Bob Kaestner and the participant of the 2014 APPAM conference for helpful comments. The views expressed herein are those of the authors and do not necessarily reflect the views of the National Bureau of Economic Research.

NBER working papers are circulated for discussion and comment purposes. They have not been peerreviewed or been subject to the review by the NBER Board of Directors that accompanies official NBER publications.

(C) 2014 by Resul Cesur, Bahadir Dursun, and Naci Mocan. All rights reserved. Short sections of text, not to exceed two paragraphs, may be quoted without explicit permission provided that full credit, including (C) notice, is given to the source. 
The Impact of Education on Health and Health Behavior in a Middle-Income, Low-Education

Country

Resul Cesur, Bahadir Dursun, and Naci Mocan

NBER Working Paper No. 20764

December 2014

JEL No. I1,I12,I15,I21,I25,I26

\title{
ABSTRACT
}

Although the impact of education on health is important for economic policy in developing countries, the overwhelming majority of research to identify the health returns to education has been done using data from developed countries. We use data from three waves of a nationally-representative health survey, conducted between 2008 and 2012 in Turkey, and exploit an education reform that increased the mandatory years of schooling from 5 to 8 years in 1997. Using exposure to the reform as an instrument for education, we find that for women ages 18-30, education has no impact on self-reported health, BMI, overweight, obesity, or on the propensity or intensity of smoking. Education does not influence women's daily consumption of fruits, vegetables, or their propensity to get a flu shot either. The same results are obtained for men of the same age group with one exception: education increases men's BMI and the propensity to be overweight and obese. Potential explanations for these findings are provided.

\author{
Resul Cesur \\ Department of Finance \\ University of Connecticut \\ 2100 Hillside Road Unit 1041 \\ Storrs, CT 06269-1041 \\ and University of Connecticut \\ cesur@business.uconn.edu \\ Bahadir Dursun \\ Department of Economics \\ Louisiana State University \\ 2326A BEC \\ Baton Rouge, LA 70803 \\ odursu2@1su.edu
}

\author{
Naci Mocan \\ Department of Economics \\ Louisiana State University \\ 3039 BEC \\ Baton Rouge, LA 70803-6306 \\ and NBER \\ mocan@1su.edu
}


The Impact of Education on Health and Health Behavior in a

Middle-Income, Low-Education Country

\section{Introduction}

Grossman's human capital model has created the theoretical foundation for the analysis of the demand for health (Grossman 1972a, 1972b). In this model health capital depreciates over time, and gross investment in health can be produced by a household production function that uses the person's own time and inputs such as medical care, diet, and cigarette and alcohol consumption. Schooling affects health because education increases the efficiency of health production; i.e. more educated individuals "produce" better health from a given set of health inputs. In contrast to this productive efficiency channel, education can also directly impact health outcomes through allocative efficiency. Under this mechanism, more educated people produce better health outcomes because they choose different input allocations in comparison to those who are less educated. Specifically, education allows individuals to acquire more information about the impacts of health inputs (medical care, cigarettes, exercise, and so on), which alters the consumption of these inputs, health behaviors, and affects health outcomes.

The positive relationship between education and health outcomes is well-documented, regardless of whether the focus is on individuals (using data on self-reported health, sick days, etc.) or whether aggregate units are analyzed (such as mortality or morbidity rates). Identification of the causal impact of education on health, however, is complicated because unobservable attributes of individuals may be correlated with their schooling as well as their health behaviors and health outcomes. Examples of such difficult-to-observe attributes include time preference and intelligence. A further complication arises because of potential reverse 
causality; i.e. poor health may cause lower educational attainment, producing a positive correlation between education and health.

A solution to endogeneity of education is to find an exogenous variation that can drive education, but that is itself not related to health outcomes. For example, de Walque (2007) used an instrumental variable approach based on the idea that college attendance could have served as a strategy for draft avoidance in the U.S. during the Vietnam War. His results showed that more education, due to exemption from military service, had a negative impact on smoking. Currie and Moretti (2003) used college openings when a woman was 17 years old as an instrument for education and showed that maternal education, instrumented this way, had a negative impact on the incidence of low birth weight.

A number of recent papers exploited variations generated by compulsory education laws to investigate the extent to which education has a causal impact on health. For example, using exposure to compulsory education laws in the United States from 1915 to 1939, Lleras-Muney (2005) reported a negative impact of education on mortality. Chou, Grossman and Joyce (2010) used the compulsory education reform implemented in Taiwan in 1968, which increased the mandatory years of education from six to nine. Using exposure to the reform as an instrument for education, they found that parents' education caused favorable infant health outcomes during the years 1978-1999. Brunello, Fabbri and Fort (2013) analyzed data on males (females) who live in seven (nine) European countries that increased compulsory years of education. The instrumental variables regressions showed that additional schooling, triggered by the education reforms, had a negative impact on the body mass index in case of females.

Some other studies, however, reported weak or no effect of education on various health outcomes using similar empirical designs. For example, Kemptner, Jürges and Reinhold (2011) 
employed an instrumental variables strategy using the compulsory education reforms implemented in West Germany between 1949 and 1969. They found that education had a negative impact on long-term illness for men, but not for women, and that education had little impact on having weight problems and had no impact on smoking. McCrary and Royer (2011) used age-at-school-entry policies in Texas and California and estimated the impact of female education on infant health. Comparing women born before and after the school entry dates, they reported only a small impact of education on birth weight and prematurity of newborns.

Clark and Royer (2013) exploited two changes to British compulsory schooling laws that increased school-leaving-age from 14 to 15 in 1947 and from 15 to 16 in 1972 . They could not find a significant impact of education on various health outcomes such as mortality or selfreported health, or on health behavior such as smoking and drinking. Similarly, Lindeboom et al. (2009), who used the 1947 reform in the U.K., could not find an impact of the increase in parental education on the health of the offspring. Albouy and Lequien (2009) could not detect a causal impact of education on mortality in their analysis of a French panel data set using two identifying changes to the school-leaving-age. Meghir, Palme and Simeonova (2012) analyzed Swedish cohorts born between 1946 and 1957 that were impacted by education reforms implemented in 1949 and 1962 which increased the compulsory years of schooling. The authors could not detect significant effects of education on mortality up to age 60. Palme and Simeonova (forthcoming) found that an exogenous increase in education, due to the same increase in in compulsory education in Sweden, has increased women's risk of breast cancer diagnosis and lowered the breast cancer survival probability.

The impact of education on health is important for economic policy, especially in developing countries. It is well-documented that education causes an increase in worker 
productivity and wages, and that the impact is larger in developing countries (Card 2001, Oreopoulos 2006, Mocan 2014.) A distinguishing feature of developing countries is that their education levels are low and health outcomes are worse in comparison to those of developed countries. For example, among the 180 countries around the world with available data, the median years of education is 8.2. Dividing countries into two groups as those with average education greater than 8.2 years, and those with average education fewer than 8.2 years, we find that life expectancy at birth is 65.5 years in the group of countries with low education, while it is 72.8 years among the high-education countries. Similarly, the infant mortality rate is 19.6 deaths per 1,000 live births in the former group, while it is 39 deaths in the latter. The tuberculosis rate is 90 cases per 100,000 residents in high-education countries, while the rate is more than twice as high (193 cases per 100,000 residents) in low-education countries. ${ }^{1}$ Thus, if education has a causal impact on health in developing countries, the importance of education as a policy lever is magnified. $^{2}$

There is, however, a dearth of information on the causal impact of education on health in developing countries. The research cited above has focused on developed countries, and data limitations prevented similar analyses from being conducted in the developing country context, although there is a sizable literature that investigates the impact of education on fertility, the use

\footnotetext{
${ }^{1}$ Country level education data are obtained from Barro et al. (2010). Infant mortality, tuberculosis and life expectancy data are from World Bank's World Development Indicators.

${ }^{2}$ A related question is the direct impact of health on economic development, the evidence on which is not clear-cut. For example, Bleakley (2007) analyzes the impact of the eradication of hookworm disease from the Southern states of the U.S. in the early $20^{\text {th }}$ century, and finds that cohorts that benefitted from the hookworm eradication program made substantial income gains. Lorentzen, McMillan and Wacziarg (2008) use cross-national and sub-national data. Their cross-sectional instrumental variables regressions show that high adult mortality promotes higher levels of risky behavior and lower investment in physical capital, and that adult mortality is a substantial determinant of economic growth. On the other hand, Acemoglu and Robinson (2007) fail to detect an impact of a country's per capita GDP and its life expectancy. Similarly, using a simulation model Ashraf, Lester and Weil (2008) find that large improvements in health lead to small gains in GDP per capita.
} 
of contraceptives and the acquisition of health knowledge in developing countries (examples include Osili and Long 2008, Cannonier and Mocan 2012, Agüero and Bharadwaj 2014).

In this paper we use micro data on a large sample of Turkish residents, based on nationwide surveys conducted by Turkish Statistical institute in 2008, 2010 and 2012. This is one of the very few papers that investigates the impact of education on health outcomes and health behavior in a developing country. Turkey is a middle-income country with per capita income of $\$ 10,900$ in 2013. Average years of education is low: 6.5 years of schooling among those who are 25 years of age or older. The main reason for the low level of education is that the mandatory years of schooling was only 5 years until 1997. An education reform law was passed quickly in August 1997, which became effective in Fall 1997. The law increased the mandatory years of schooling from 5 years to 8. The details of the reform are explained in Section II below. Exposure to this reform is used as an instrument for completed schooling to identify the impact of education on various health outcomes and the consumption of health inputs. ${ }^{3}$

The data contain detailed information on personal background characteristics of individuals, along with information on self-reported health, height, weight, and various measures of smoking. We also analyze such health behaviors as consumption of fruit, consumption of vegetables, and flu vaccinations, although our primary focus is on smoking and obesity because these are two major preventable causes of death (Mokdad et al. 2004). About 1.5 billion people around the world were estimated to be overweight or obese in 2008 (Popkin et al. 2012). Furthermore, as indicated by the World Health Organization, "Almost 6 million people die from tobacco use each year, both from direct tobacco use and second-hand smoke. By 2020, this number will increase to 7.5 million, accounting for 10 percent of all deaths. Smoking is

\footnotetext{
${ }^{3}$ Some recent papers also employed instrumental-variables regressions using this Turkish education reform. Cesur and Mocan (2013) found that education, driven by the reform, impacts women's religiosity; Dincer, Kaushla and Grossman (2014) and Gunes (2013) report that education lowers the incidence of pregnancy and fertility.
} 
estimated to cause about 71 percent of lung cancer, 42 percent of chronic respiratory disease and nearly 10 percent of cardiovascular disease. The highest incidence of smoking among men is in lower-middle-income countries" (WHO 2010). Obesity and smoking are listed among the most important public health challenges faced by developing countries, and the reports of the World Health Organization (WHO) and the World Bank (WB) frequently stress the importance of education in promoting health and health behaviors in these countries (WHO, 2009; WB, 2011). ${ }^{4}$

We find that in this middle-income country, education has no statistically significant impact on self-reported health, BMI, smoking, consumption of fruits, consumption of vegetables or flu vaccinations for women ages 18-30. Similarly, in case of men, education has no impact on these health outcomes and health behavior, with the exception of BMI. An increase in education, due to exposure to the education reform, has a positive impact on BMI and the propensity to be overweight/obese in case of men.

In section II, we provide the institutional details of the education reform. Section III presents the empirical framework, and Section IV discusses the data. Section V presents the results and extensions; Section VI is the conclusion.

\section{The 1997 Compulsory Schooling Reform in Turkey as the Source of Identification}

In August 1997, the Turkish Parliament passed a law to modify secular mandatory schooling. Prior to this education reform, mandatory education was limited to five years of primary education. The reform increased the mandated years of education to eight years by combining the primary and middle schools. The reform, however, did not involve any changes

\footnotetext{
${ }^{4}$ The Director-General of the WHO, Dr. Margaret Chan, started her speech in the 2010 United Nations Summit on the Millennium Development Goals (MDGs) by stating "Education and health go hand in hand. The evidence demonstrating the links is overwhelming." http://www.who.int/dg/speeches/2010/educationandhealth_20100920/en. Education for All campaign of the United Nations repeatedly refers the potential health improvements as one of the key external benefits of extending primary and secondary education (UNESCO, 2000).
} 
in curriculum; neither the course contents nor the composition of courses are affected by the reform (Dulger 2004).

The law went into effect immediately in Fall 1997, and the students who were enrolled in the fifth grade in Fall 1997 were required to continue their schooling until the end of the eight grade. On the other hand, students who had already completed the fifth grade by the Summer 1997 were exempt from the mandate. The law was enacted very quickly, for political reasons. During the time period when the law was enacted, Turkey was involved in negotiations for the European Union membership and the government was concerned that European Union negotiations would not proceed without the implementation of a reform that increased the level of education in Turkey (Dulger 2004). The law was also an attempt to limit the extent of religious education. Details on this point and the political landscape in Turkey in 1997 can be found in Cesur and Mocan (2013).

The relevant Turkish law states that a child may start the first grade in the Fall if he/she is 72 months old at the end of that calendar year. ${ }^{5}$ This means that those who are born towards the end of 1986 (in October-December) could start school in 1992. At the same time, in Turkey the age cut-off is not strictly enforced and children are allowed to start school if they are on the margin of the 72-month cut-off. Thus, those who are born in early 1986 would start the first grade in Fall 1991, rather than Fall 1992. This means that although most children who were born in 1986 would have enrolled in the first grade in 1992 and therefore have completed the fifth grade in Summer 1997 (therefore, exempt from the mandate of the law), some other children who were also born in 1986 have completed only the fourth grade and these children were impacted by the reform. Therefore, in the benchmark models of the paper we exclude those born in 1986, although as we show later, including them does not alter the results.

\footnotetext{
${ }^{5}$ Resmi Gazete; Friday, 7 August 1992, Section 14.
} 


\section{Empirical Framework}

The relationship between health outcomes and education at the individual level is depicted by Equation (1) below, where $\mathrm{H}_{\mathrm{i}}$ stands for a particular health outcome (e.g. selfreported health status, obesity) as well as various measures of tobacco consumption. In addition, we also investigate the consumption of other health inputs such as fruits, vegetables, and flu vaccinations. Middle School represents a binary indicator for holding at least a middle school degree $^{6}$

$$
H_{i}^{S}=\propto+\beta_{i}^{S} \text { Middle School } l_{i}^{S}+Z_{i}^{S \prime} \Psi+\varepsilon_{i}^{S}
$$

$\mathrm{Z}$ is a $(\mathrm{kx} 1)$ vector of control variables which includes linear and quadratic terms in age and year-of-birth, and region of residence fixed-effects for the 12 regions of the country. To account for potentially different trends in health by region, we follow Stephens and Yang (2014), and also estimate alternative specifications in which we allow birth year trends differ by region (i.e., controlling for interactions between region fixed effects and year of birth in addition to other controls). Standard errors are clustered at the region-by-birth cohort level. Alternative ways of clustering (e.g. year of birth-by-treatment) provided almost identical standard errors. As explained in the data section, we use three cross-sectional surveys, registered in three waves, in two-year intervals. The superscript $s$ identifies the wave of the survey; i.e. $s$ in $\{1,2,3\}$.

Estimating Equation (1) by OLS produces biased estimates of $\beta$. This is because educational attainment is likely to be correlated with a number of unobservable factors that may also impact health outcomes. Alternatively, reverse causality may exist and health outcomes may impact the level of education. To address the endogeneity of educational attainment, we exploit the exogenous variation in the propensity of middle school graduation induced by the

\footnotetext{
${ }^{6}$ The HS surveys do not include information on years of schooling. Instead, information on the literacy status and educational attainment of survey participant were obtained based on the following options: literate, less than basic 5year education, basic 5-year diploma, middle school diploma, high school diploma, and college education.
} 
Education Reform of 1997. As described in the previous section, birth cohorts born after 1986 were mandated to complete middle school (i.e., 8 years of schooling), while those who were born prior to 1986 were not bound by the law.

We employ an instrumental variables strategy and use exposure to the education reform as an instrument for having middle school diploma, as depicted by Equation (2).

$$
\text { Middle School }{ }_{i}^{S}=\pi+\gamma \text { Reform }{ }_{i}^{s}+Z_{i}^{s \prime} \Omega+\mu_{i}^{s}
$$

where Reform is a binary indicator that takes the value of one for those who were born after 1986, and it takes the value of zero for those who were born before 1986. As discussed earlier, it is uncertain whether those who were born in 1986 were affected by the reform. Hence, the birth cohort of 1986 is omitted from the main regression specifications. ${ }^{7}$

By design, those who are younger in a particular survey year are more likely to have been exposed to the reform and those who are older are likely to have missed the reform. For example, people who were born in 1985 are 25 years old in 2010, and those who are born in 1987 are 23 years old in that same year. The former group is not treated by the reform, while the latter group was exposed to it. If health behaviors are changing with age for reasons unrelated to education, it would be difficult to separate the impact of education from that of aging. Our data set, however, contains three waves of the same survey, registered in 2008, 2010 and 2012. This means the age effect can be separated out from the cohort effect. For example, somebody who is 25 years old in 2012 was born in 1987 (exposed to the reform), while the person who was 25 years old in 2010 was born in 1985 (not exposed to the reform). Thus, having access to three

\footnotetext{
${ }^{7}$ We also estimated all our models by coding the Reform variable in two alternate ways: Reform $=0.33$ if birth year=1986; and Reform=0.5 if birth year=1986. The results did not change.
} 
waves of the survey that covers a time span of 5 years (2008-2012) allows us to isolate the impact of age from the impact of treatment by the reform.

Inserting equation (2) into Equation (1) enables us to investigate the impact of exposure to the reform on health outcomes and health behaviors. This reduced-form relationship is depicted by Equation (3):

$$
H_{i}^{S}=\delta+\lambda R \text { eform } \text { for }_{i}^{S \prime} \Phi+e_{i}^{S}
$$

where $\lambda$ represents the reduced form, (the intention-to-treat), effect of the reform.

\section{Data}

We use data drawn from the three available waves of the Turkish Statistical Institute's Health Survey (HS) registered in 2008, 2010, and 2012. The 2008 and 2010 waves include 20,624 and 20,200 participants, respectively; and the 2012 survey include 37,979 individuals. The goal of the HS is to provide nationally representative estimates of health indicators in Turkey. Three separate survey questionnaires are provided for the age groups 0-6, 7-14, and 15 and older. ${ }^{8}$ For those who are 15 and older, the survey collects detailed health information, including self-reported health status, smoking habits, chronic diseases, height and weight. Also included are personal background characteristics, such as education, gender and residential location. Our estimation sample includes those who were between 18 and 30 years old at the time of the survey.

The key independent variable, Middle School, is a binary indicator of whether the individual holds a middle school diploma or a higher degree. The survey does not include information on years of schooling. Instead, individuals were classified as being literate, having

\footnotetext{
${ }^{8}$ For those respondents who are younger than 15 , the parent or guardian completed the survey. By our empirical design, people who are younger than 16 are not in our sample.
} 
less than basic 5-year education, basic 5-year diploma, middle school diploma, high school diploma, and college education. Middle school diploma corresponds to 8 years of education. The mandate of the schooling reform was to provide at least a middle school education, impacting the cohorts of children starting with those who were born in 1987. Figures 1 and 2 display the proportion of males and females who have at least 8 years of education (Middle School diploma), by birth cohort. The data used in the figures consist of all three waves of the HS. ${ }^{9}$ The proportion of individuals with at least a middle school diploma has been rising with each younger cohort. For example, in the birth cohort of 1972, 28 percent of women and 45 percent of men have a middle school education or higher, whereas the rates are 51 percent and 75 percent, respectively, among those born in 1985. The first cohort that is fully exposed to the reform is that of 1987. As shown in Figures 1 and 2, the proportion of individuals with at least a middle school diploma jumps to about 70 percent for women and almost 90 percent for men among the first cohort fully impacted by the law; and plateaus at around 87 percent for women and 95 percent for men. ${ }^{10}$ These figures are very similar to those reported by other researchers who analyzed the same education reform but used different data sets (Cesur and Mocan 2013, Mocan 2014).

We know the birth year of the respondents, but not their exact birthday. This is not an issue because the birthday does not provide useful information for any analysis that uses this Turkish education reform. This is because, as mentioned in Section II above, the exposure to the law cannot be determined by the birth date of the student. More specifically, in Turkey the

\footnotetext{
${ }^{9}$ Figure 1 is utilizing 13,008 observations (approximately 600 females in each birth cohort), and Fig 2 uses 10,146 males (about 500 males in each cohort).

${ }^{10}$ Mandatory schooling is free in Turkey and non-attendance is subject to fines (http://mevzuat.meb.gov.tr/html/24.html) although these fines are not strictly enforced (http://spm.ku.edu.tr/wpcontent/uploads/pdf/okulterk.pdf). Consequently, even though the middle school completion rates increased above the 90 percent level after the reform was in effect, perfect compliance could not be achieved. However, these compliance rates are similar to those observed in European countries (see Brunello et al 2013).
} 
school starting age is not determined by the student's age in September. The law states that "Students who are 72 months old by the end of the calendar year (emphasis added) can start school in September" (Resmi Gazete, dated August 7, 1992. No: 21308, page 4, Section 14). ${ }^{11}$ This means that children born in September, October, November or December 1986 were exempt from the mandate of the law. Furthermore, given the fact that the 72-month-cutoff is not strictly enforced, even those who are born in January 1987 may have started school in 1992, thus avoiding the mandate. The upshot is that information on the birthday of the child would not, in most cases, have provided any additional information as to whether a particular child was bound by the mandate.

Self-reported health status is determined by the question of "How is your health in general?" which is asked in all three waves. Potential answers are; very good, good, average, bad, very bad. The variable Good Health takes the value of 1 is the respondent declared his/her health status as good or excellent, and zero otherwise. Eighty-eight percent of men and 82 percent of women declare that their general health is in good or excellent shape.

Self-reported height and weight are also available in all three waves of the HS. Using this information, we calculate the body mass index $(B M I)$ for each individual, which is employed as another health outcome. ${ }^{12}$ We also construct three binary variables to indicate whether the person is underweight, overweight or obese, or obese. Specifically, Underweight takes the value of 1 for individuals for whom the BMI score is less than 18.5, and 0 otherwise.

Overweight/Obese is equal to 1 for respondents with a $B M I$ greater than or equal to 25 , and zero

\footnotetext{
${ }^{11}$ http://www.resmigazete.gov.tr/main.aspx?home=http://www.resmigazete.gov.tr/arsiv/21308.pdf\&main=http://ww w.resmigazete.gov.tr/arsiv/21308.pdf

${ }^{12} \mathrm{BMI}=[($ Weight in Kilograms $) /($ Height in Meters Squared $)]$. BMI does not differentiate between the proportion of fat and the proportion of muscle/bone in total weight. This could be especially important in determining the impact of weight and body composition on outcomes such as wages (Burkhauser and Cawley 2008)
} 
otherwise. The dichotomous variable Obese is coded as 1 if $B M I$ is at least 30, and zero otherwise.

As Panel B of Table 1 shows, the average BMI in the sample is 24 for men and 23 for women. Twenty-six percent of women and 32 percent of men are either overweight or obese. If women are more concerned than men about their weight, the tendency to underreport weight in the survey could be higher for women than men; and this could be one reason for the lower overweight/obesity rates among women. In our analysis, however, we will divide the sample by sex and investigate the impact of education on BMI within each sex. The obesity rate is five percent among men, and six percent among women.

Questions on tobacco use were asked in the 2010 and 2012 surveys. We construct three dichotomous indicators representing smoking habits. Ever Smoked is equal to 1 if the individual responded in the affirmative to the question "Have you ever regularly (at least 100 units per year) consumed tobacco products?" The variable Current Smoker takes the value of 1 if the respondent currently consumes tobacco products (at any frequency; i.e. every day, or once-in-awhile). While the questions refer to the use of tobacco products, cigarette consumption is by far the largest item in tobacco consumption in Turkey. Consumption of other tobacco items such as chewing tobacco, smoking cigar, pipe or hukka are trivial in comparison to cigarettes. Among those who indicated that they used tobacco products, 98 percent smoke cigarettes. As Panel C of Table 1 shows, 49 percent of men and 16 percent of women are smokers in Turkey (in 2010 and 2012).

Smokes Every Day is another dummy variable that indicates if the respondent consumes tobacco products every day, conditional on being a smoker currently. Among those who smoke, 90 percent of men and 76 percent of women smoke every day. The question on the average 
number of cigarettes smoked per day was asked to those who smoke every day. Thus, among those who smoke regularly (i.e. every day), the average number of cigarettes smoked per day is 12 for men, and about 9 for women. ${ }^{13}$

Table 1 also presents the summary statistics by exposure to the education reform. We restrict the sample to those who are born between 1982 and 1990. This means that we utilize four cohorts that are exposed to the education reform (those born between 1987-1990) and four cohorts that missed the reform (born between 1982-1985). The age range of the sample is 18-30 and the age distributions by sex are presented in Figures 3 and $4 .^{14}$

Panel A is based on the sample where information on self-reported health is available and Panel B pertains to the individuals with non-missing height and weight information. Questions displayed in these panels were asked in all three waves (2008, 2010 and 2012). Columns (2) and (5) of Table 1 present the means and standard deviations of the variables for those who are in the control group (not treated by the reform), and columns (3) and (6) pertain to those who are exposed to the reform. Consistent with Figures 1 and 2, for both males and females, the proportion with at least a middle school diploma is higher in the treatment group. Those in the treatment group have slightly better self-declared health; and the rate of overweight/obesity is lower in the treatment group (which is younger in comparison to the control group).

Panel C of Table 1 presents the descriptive statistics related to tobacco consumption. Because these questions were not asked in 2008, this sample is smaller in comparison to that in

\footnotetext{
${ }^{13}$ Because the question on Smoking Every Day is conditioned on being a current smoker, and the question on the Number of Cigarettes is conditioned on smoking every day, the sample sizes that apply to these questions are smaller to those of the other questions on smoking.

${ }^{14}$ In the regressions we also use the sample of individuals who are born between 1983 and 1989, in addition to the 1982-1990 cohorts.
} 
Panel A. All three measures of smoking indicate that the propensity of smoking is lower in the treatment group.

\section{Results}

\section{OLS Estimates}

We first present the OLS results, where educational attainment, measured by having at least a middle school diploma, is assumed to be exogenous. The estimates obtained from these OLS models are likely to be biased, but it is nevertheless interesting to compare them to the estimates obtained from the instrumental variables regressions. Table 2 presents the OLS results of health outcome regressions. All models include linear and quadratic terms of age and year-ofbirth, as well as region-fixed effects. Standard errors are clustered by region-by-birth cohort. All regressions in Table 2 (as well as in Table 3) use those who were born between 1982 and 1990. According to these OLS results, having a middle school diploma (as opposed to having an elementary school degree or no degree) has a positive impact on self-reported good health for both men and women. Also, education has a negative impact on women's BMI. In case of women, having at least a middle school degree increases the propensity for being underweight and it reduces the propensity of being overweight and obese.

The OLS estimates in Table 3 suggest that education reduces the propensity to smoke for men, but it has the opposite effect for women; i.e. having a middle school diploma has a positive impact on the likelihood of smoking for women.

\section{Instrumental Variables Estimates}

Because the OLS results of Tables 2 and 3 are not credible, we report the instrumental variables results, where having at least a middle school education is instrumented by exposure to 
the education reform. Table 4 presents the results of estimating equation (2), where the propensity of having a middle school diploma is explained by the exposure to the reform as well as all other covariates. Two alternative samples are employed. The first sample uses individuals who are born between 1982 and 1990. In this sample there are four cohorts on each side of the treatment year (see the vertical lines in Figures 1 and 2). The second sample (employed in the regressions reported in column 2) narrows the window around the treatment. It contains people who were born between 1983 and 1989. The advantage is that individuals are more similar in age, but the disadvantage is that the sample size is smaller. Table 4 shows that exposure to the reform has a statistically significant impact on the propensity to have a middle school education or higher. The impact is about 11-15 percentage points for men and 19-22 percentage points for women. ${ }^{15}$

Table 5 presents the instrumental variables results of the impact of education on selfreported health (top panel), on BMI, the propensity to be underweight, overweight/obese, or obese (middle panel); and on indicators of smoking (bottom panel). Standard errors are clustered by region-by-birth cohort. Alternative ways of clustering (e.g. year of birth-by-treatment) provided almost identical standard errors. The first two columns display the results obtained from the sample of men, and columns (3) and (4) pertain to women. The top panel of Table 5 shows that the first-stage regressions are powerful for both men and women, with F-values ranging from 12 to 36 , depending on the sample. The impact of education on self-reported health is not statistically different from zero for either men or women, and one of the two point estimates for men is negative.

\footnotetext{
${ }^{15}$ Mocan (2014) who used much larger sample sizes (about 75,000 females and 69,000 males) but reported an impact of the reform on the probability of having a middle school diploma by very similar magnitudes: 17 percentage points for women and 13 percentage points for men.
} 
Panel B of Table 5 presents the instrumental-variables results where BMI, and the propensities of being underweight, overweight/obese, or obese are used as health outcomes. The first-stage regressions are once again powerful. For women, education has no impact on BMI or on the propensity of being overweight or obese. In the sample of women who were born between 1983 and 1989 (column 4), the impact of middle school education on being underweight is negative, but the coefficient is significant only at the ten-percent level, and when the sample is increased to include those women who are born in 1982 and in1990 (column 3), the coefficient gets smaller and loses its statistical significance.

Columns (1) and (2) of Panel B in Table 5 show that middle school diploma has a positive and statistically significant impact on men’s BMI. Having a middle school diploma, which is associated with an extra three years of schooling in comparison to the control group, increases men's BMI by 7 points from a base of about 24 . This means that an additional year of schooling increases men's BMI by about almost 10 percent. Similarly, the results in Panel B of Table 5 indicate middle school education has a positive impact on men's propensity to be overweight or obese.

These results are in contrast to those obtained from the OLS regressions, reported in Table 2. Specifically, the positive impact of education on self-reported health disappears when we estimate the model by instrumental variables, accounting for the endogeneity of education. The insignificant impact of education on BMI, obtained by OLS, becomes significant in the instrumental-variables specification for men; and the opposite happens for women.

The data used in panels A and B of Table 5 are obtained from the three available waves of the HS (2008, 2010 and 2012). Panel C displays the results pertaining to smoking. Because smoking questions were not asked in 2008, we utilize two waves of the HS survey for this 
analysis. Consequently, sample sizes are smaller in the regressions displayed in Panel C. As can be seen in the first part of Panel $\mathrm{C}$, an increase in schooling, due to exposure to the education reform, has no significant impact on any indicator of smoking. This result too, is in contrast to that obtained from simple OLS regressions, reported in Table $3 .^{16}$ The middle and bottom section of Panel C of Table 5 present results of regressions that investigate the intensity of smoking, conditional on smoking cigarettes. Because these samples exclude individuals who do not smoke, they are smaller and the first-stage regressions are not powerful.

It can be argued that there might be measurement error in reported smoking, especially in case of females, if there is stigma attached to smoking. Non-systematic measurement error in reported smoking does not produce a bias given that smoking is the dependent variable. If the more educated have a tendency to underreport their true smoking propensity because they are aware of the consequences of their unhealthy behavior and do not want to reveal the extent of the smoking in the survey, one would obtain a larger negative impact of education than the true impact. Given that we find no impact of education, this is not a concern.

\section{Anti-Smoking Campaigns}

Since 2006, the Turkish Government has implemented three main policies to curb smoking. ${ }^{17}$ Specifically, a law was passed in January 2008 to ban indoor smoking from public spaces such as offices, restaurants and taxi cabs. The law became effective in two phases: the first phase in May 19, 2008 and full implementation in July 19, 2009. In addition, a different law

\footnotetext{
${ }^{16}$ Tansel and Karaoglan (2014) use the same data as we do, but consider education as exogenous, and rely on OLS regressions. They estimate their models using the combined sample of men and women who are older than 25 years of age. We find very similar results when we employ the estimation sample of Tansel and Karaoglan (2014) and use OLS as they do.

${ }^{17}$ The WHO Report on the Global Tobacco Epidemic (2013) acknowledges the tobacco control efforts in Turkey as suggests that other developing countries should follow the policies implemented towards discouraging smoking in Turkey.
} 
mandated that starting in January 2010 all packs of cigarettes should contain warning labels and pictures depicting harmful effects of smoking. ${ }^{18}$ Some examples of these warning labels and pictures are presented in Appendix Figure 1. The first warning labels on packs of cigarettes in Turkey was implemented starting in January 2006. These labels were similar to the warning signs shown in Appendix 1, but they did not include any pictures. The warning labels contained statements such as "Smoking while pregnant hurts the baby," "Smoking may cause a slow and painful death," "Smoking causes lung cancer." In addition, significant increases in cigarette taxes were implemented in 2009 and 2010. (Yurekli et al. 2010).

Because these anti-smoking campaigns were initiated in 2006, younger generations, who had a higher chance of being treated by the education reform, were exposed to the anti-smoking campaigns more intensely. Ignoring the potentially negative impact of the anti-smoking campaigns on smoking may create a negative bias in the estimated impact of education on smoking. Even though we do not find an impact of education on smoking and despite the fact that half of the estimated coefficients are positive (see table 5, Panel C), we nevertheless investigate the sensitivity of the results to exposure to anti-smoking campaigns.

To control for the potentially negative effect of these campaigns on smoking, we created measures of exposure to anti-smoking campaigns and used them as additional explanatory variables to explain the smoking propensity. For example, given that these campaigns have become more intense over time and that older individuals in the sample were exposed to them for longer periods of time, we interacted the reform indicator with the year-of-birth and used it as an additional control. Adding this variable had no impact on the results. Alternatively, including a dummy variable for younger cohorts (born in 1988, 1989 and 1990), who were exposed to the

\footnotetext{
${ }^{18}$ A grace period was provided to market cigarettes that were produced before Jan 1, 2010. These packs, that did not contain pictures, could be sold until June 30, 2010.
} 
anti-smoking campaigns at younger ages, had no impact on the results. ${ }^{19}$ Finally, we excluded the 2012 wave of the survey and estimated the smoking models using only the 2010 survey. Because indoor smoking bans and warning labels with pictures became effective after Summer 2009 and Winter 2010 respectively, there was limited exposure of the respondent to these laws by the time they took the survey in 2010 . Nevertheless we obtained similar results to those shown in Table $5 .^{20}$ These results indicate that exposure to the warning labels on cigarettes have no impact on the estimated impact of education on smoking.

\section{Health Information}

The allocative efficiency hypothesis of health production assumes that more educated individuals have more knowledge about the health production function and that the more educated react to health information more powerfully than the less-educated. Put differently, education increases information about the true impact of health inputs on health outcomes. In support of this hypothesis, Price and Simon (2009) find that during the three-month period after the publication of an article in the New England Journal of Medicine about the risk of a vaginal birth following a previous C-section birth, the incidence of such births dropped more significantly among the more educated mothers. This result suggests that more educated people absorb new information more quickly, which may then change their behavior. Aizer and Stroud (2010) report that more educated mothers reduced their smoking after the release of the 1964

\footnotetext{
${ }^{19} \mathrm{We}$ also tried other, more ad hoc specifications. For example, assuming that smoking behavior can most be impacted by age 25 , we created a year-of-exposure variable until the year in which the respondent was age 25 . For example somebody who was born in 1987 and surveyed in 2010, was exposed to anti-smoking campaigns (which started in 2006) for 5 years. Somebody else who was also born in 1987 but was surveyed in 2012 was exposed for 7 years. The results did not change.

${ }^{20}$ The sample sizes are smaller when we exclude the 2012 survey, and as a result, the first-stage is not significant for males. Consequently, the instrumental-variables estimates for men blow up. The reduced-form estimates, however, were in line with those reported earlier.
} 
Surgeon General Report on smoking and health while the less-educated did not. While these findings support the allocative efficiency hypothesis because they imply that education increases information about the true impact of the inputs on health, Mathios (2000) could not find evidence to support the hypothesis that more educated shoppers react differently to the information content of salad dressing labeling than the less-educated. Altindag, Cannonier and Mocan (2011) analyze data from the 1997 and 2002 waves of the NLSY97 and find no relationship between education and health knowledge for individuals with a terminal high school degree.

The Turkish Health Surveys include a question that asks the respondents whether they believe that the warnings on packs of cigarettes are effective. Specifically, the question is " $D o$ you think the warnings on the packages of tobacco products are effective (in motivating people) to quit?" Thirty-seven percent of the sample thinks that these warnings are effective. We used the variable that specifies whether the individual thinks the warning signs are effective as an outcome and estimated the same instrumental-variable specification. The results showed that, both for men and for women, education had no impact on people's belief in the efficacy of the warning signs.

It is possible that the beliefs about the effectiveness of warning labels/pictures might depend on exposure to smoking; i.e. people who reside in areas with high smoking rates may have different perceptions on the effectiveness of the warnings in comparison to those who live in low-smoking areas. We calculated the smoking rates by region and divided the regions into two groups: above-median smoking regions and below-median regions. Estimating the models by this classification revealed that education does not alter individuals' perceptions of the effectiveness of smoking labels, regardless of whether the live in a high-smoking or lowsmoking region. When we re-estimated these models among those who are current smokers and 
among non-smokers, we found the same result: education had no impact on people's beliefs regarding the efficacy of the warning labels, regardless of whether they were smokers.

Finally, we ran the models by adding the Current Smoker variable as an explanatory variable and interacting it with Middle School Diploma. This specification is defendable as the results of Table 5 show that smoking (either at the intensive or at the extensive margin) is not influenced by education. This specification allows us to investigate whether the belief on the effectiveness of warning labels/pictures depends on whether the individual himself/herself is a smoker, and whether education has a differential impact on this belief by smoking status. We found that neither the smoking status of the person nor education had an impact on the belief regarding the effectiveness of warning labels.

Finally, we estimated reduced-form regressions, as depicted by Equation (3), that correspond to the models displayed in Table 5. These reduced-form results are displayed in Table 6. They represent the impact of having been part of the cohorts that were exposed to the reform. As expected, exposure to the reform has no impact on self-reported health or smoking, but it has positive impact on men's BMI and obesity. ${ }^{21}$

In summary, the results presented in Table 5 indicate that education has no impact on self-reported health, body weight or smoking behavior for young adult women in Turkey. For men, we find that education increases BMI and obesity. The detrimental impact of education can emerge because of the influence of education on income. It is conceivable that an increase in earnings, due to schooling, promotes the consumption of more calories, generating an increase in BMI. This hypothesis is consistent with the pattern documented in recent research which shows

\footnotetext{
${ }^{21}$ The IV-coefficients reported in Table 5, can be recovered by taking the ratio of the reduced-form coefficients in Tale 6 and the first-stage coefficients in Table 4.
} 
an increase in BMI, obesity and overweight in developing countries over time, arguably the result of increased incomes ( $\mathrm{Ng}$ et al. 2014).

\section{Income Effect?}

If personal income has a positive effect on BMI conditional on education, omission of income from the analysis would bias the coefficient of education upwards in BMI and obesity regressions. For example, Cutler and Lleras-Muney (2010) analyzed the extent to which the impact of education on health behaviors is influenced by controlling for background variables. They found that the effect of education is reduced when the regressions include income, health insurance and family background characteristics. And, there exists recent research reporting detrimental impact of income on health. For example, using three cross-section surveys from England, Adda et al. (2009) found that permanent income shocks lead to poorer health behavior. Schmeiser (2009) used the exogenous variation in Earned Income Tax Credit in the U.S. and reported that higher income raised the probability of being obese for women. Boyce and Oswald (2012) found that people's psychological well-being declined after a job promotion in Britain. In our case, lack of well-measured income data prevents us from investigating the extent to which income is responsible for the detrimental impact of education on men's BMI. ${ }^{22}$

The education reform analyzed in this paper covered the entire country and all cohorts starting with those born in 1987. Consequently, there are general-equilibrium effects of the reform. For example, although the wage impact seems to have been concentrated on working women rather than men (Mocan 2014), personal incomes nevertheless may have risen because of

\footnotetext{
${ }^{22}$ Although not directly related to our work because they focus on elderly people, Cawley et al. (2010) could not find an impact of income, generated by Social Security Notch in the U.S, on BMI among the elderly. Snyder and Evans (2006) used the same identification strategy and reported higher mortality rates related to higher income.
} 
increased education. To investigate the extent to which the impact of education on BMI is capturing the impact of income on BMI, we ran the models by controlling for household income. The Health Surveys do not contain information on personal income, but they contain information on family income. Binary indicators for 10 family income categories that are available in the survey are included as additional control variables. The results showed that the coefficients of education and their standard errors were almost identical to those presented in the benchmark models of Table 5 .

When we added occupation dummies to the models to control for any potential impact of the respondent's occupation on BMI overweight and obesity propensity, neither the point estimates nor the standard errors were impacted meaningfully. ${ }^{23}$ Finally adding family income and occupation jointly did not alter the coefficients either. Although this result suggests that the impact of education on BMI is not attributable to an income effect, we should emphasize that income is measured as family income, not as personal income, and that it is only an estimate provided by the respondent. Thus, we cannot reject, with confidence, the conjecture that measurement error in family income makes it difficult to investigate whether the positive impact of education on BMI is working through an income effect.

\section{Education and Other Health Behaviors}

In this section we investigate if education has an impact on some other health behaviors such as consumption of fruits, consumption of vegetables, and the propensity to have a flu shot. The variable Daily Fruit Consumption takes the value of one if the respondent indicates that

\footnotetext{
${ }^{23}$ The occupation categories are: Member of Armed Forces; Legislator, Senior Official, or Managers; Professional; Technician or Associate Professional; Clerk; Service or Shop and Sale Market Worker; Skilled Agricultural or Fishery Worker; Craft and Related Trades Worker; Plant and Machine operator or Assembler; Elementary Occupation Holder. The left-out category includes students and those who are not in the labor force.
} 
he/she eats fruit at least once a day. Daily Vegetable Consumption gauges consumption of vegetables in the same exact way. Flu Shot-Last 2 Years takes the value of one if the respondent has received a flu shot this year of last year. ${ }^{24}$ Flu Shot-Ever is a dichotomous variable to indicate if the person has ever received a flu shot. Fifty-five (49) percent of women (men) indicate that they consume fruit each day. The rates are 66 percent for women and 60 percent for men regarding daily vegetable consumption.

Fifteen percent of Turkish men and 10 percent of Turkish women indicated that they have received at least one flu shot during their lives (sample age range is 18-30). Only seven percent of both sexes have received a flu shot during the least two years. The means of these variables are very similar between the control and treatment groups.

The results of the instrumental-variables regressions for these health behaviors are displayed in Table 7. The point estimates of the impact of education are negative in all regressions, other than the flu shot regressions for females. The estimated impacts, however, are never statistically significant, indicating that education has no impact on the consumption of fruits, vegetables, or the propensity to receive a flu shot.

\section{Robustness}

To investigate the robustness of our results, we tried a number of different specifications. In our main specifications, the birth cohort of 1986 was excluded from the analysis sample. This is because, as discussed in Section II, by Turkish law, it is unclear whether those who are born in 1986 are impacted by the reform. Nevertheless, we investigated the sensitivity of the main

\footnotetext{
${ }^{24} \mathrm{We}$ also used a variable that measures if the person has received a flu shot in the current calendar year, and could not find an impact of education. The mean value of this variable in the sample was very low: 0.02; arguably because the answer would depend on the month of the survey is given. Given that flu vaccinations are mostly given the Fall, people who are surveyed in the Winter, Spring and Summer months are likely to indicate that they have not received a flu shot "this year" (since January).
} 
findings to the inclusion of the 1986 birth cohort. In order to approximate the probability of treatment for that group we assigned two alternate values for exposure to the reform (i.e., Reform $=0.33$ and 0.5 ). These results, which are not reported in the interest of space, show that our baseline findings remain unchanged.

Our sample includes people with any level of education. To investigate the sensitivity of the results to the educational composition of the sample, we restricted the sample to those for whom the educational attainment is less than a college degree, and alternatively to those for whom the highest degree earned is middle school diploma (8 years). The results, once again, were not altered.

The benchmark models do not include variables that may have been impacted by education. An example is residency in an urban area. It is conceivable that people migrate from rural to urban areas as a result of higher educational attainment. Other examples include labor force participation, occupation, and marital status. Adding these variables to the models one-byone or jointly did not alter the results.

\section{Heterogeneity}

To investigate the extent to which results vary by sub-group, we estimated the models by dividing the sample into two groups: individuals with family incomes above or below the median. Table 8 presents the results obtained from the sample of people with below-median family income. The results are consistent with those obtained from the full-sample, reported in Table 5. For women, education still has no impact on any outcome analyzed. For men, earlier results hold regarding BMI and obesity, although the point estimates are smaller: an increase in education raises the BMI and increases obesity in this group of low-income men. The results obtained from the sample of individuals with above-median family income are reported in 
Appendix Table A1. Among this group of individuals, education has no impact on any health outcome, including BMI. In these models, and for men in particular, the first-stage regressions are not very informative, which reduces the reliability of the estimates.

We also estimated the models by labor market status (working or looking for a job, vs. not in the labor force) and marital status (never-married vs. ever-married). In no case did we detect results that were different from those reported in Table 5, although in some cases (e.g. women who are not in the labor force) the sample sizes were too small for reliable inference.

This analysis indicates that the main results reported in Table 5 hold in various subgroups and that the only statistically significant impact of education is found in the sample of men and when BMI and overweight/obesity are used as health outcomes.

\section{Conclusion and Discussion}

Although theoretically well-determined, the causal impact of education on consumption of health inputs and health outcomes is difficult to establish empirically. This is because education is correlated with unobservable attributes of individuals that can also impact health behaviors and health outcomes. To determine the causal impact of education on health, recent research employed identification strategies that involved finding instruments which moved individuals' education levels, independent of their health outcomes. A widely-used strategy is to rely on education reforms that changed the mandatory years of education of particular cohorts in a country, without altering the minimum years of education mandated for older cohorts in that same country. Papers that used this identification strategy analyzed data from developed countries, and reported conflicting findings as to the impact of education on health. While some research revealed a positive impact of education on health outcomes (e.g. Brunello et al. 2013, 
Chou et al. 2010, Lleras-Muney, 2005), others could not find a significant impact (e.g. Clark and Royer, 2013, Meghir, Palme and Simeonova 2012, Lindeboom et al. 2009). Inference from developing countries, based on exogenous variation in education, is extremely limited.

In this paper we analyze a nationwide survey from the Republic of Turkey, which is a middle-income, low education country with per capita income of less than 11,000 in 2013, and average education of 6.5 years among those who are 25 years or older. We exploit an education reform, implemented in 1997, that increased the mandatory years of education from an elementary school diploma (5 years of schooling) to a middle school diploma (8 years of schooling). The education reform law was passed by theTurkish Parliament in Summer 1997 and implemented in the Fall of the same year. Cohorts born after 1986 were exposed to the mandate of the law and had to complete eight years of schooling, while those who were born before 1986 were exempt from the mandate.

We use a large nationwide health survey conducted by the Turkish Statistical Institute in 2008, 2010 and 2012 to identify the causal impact of education on self-reported health, body mass-index (BMI), the propensity to be overweight and obese, and a variety of smoking measures. We also investigate the impact of education on consumption of such health inputs as fruits, vegetables, and flu vaccinations. We focus on individuals who are between the ages of 18 and 30 at the time of the survey (born between 1982 and 1990).

Exposure to the reform is used as an instrument for educational attainment. Consistent with other studies that exploited the same Turkish education reform, but used different data sets (Mocan 2014, Kirdar et. al. 2014, Cesur and Mocan 2013), we find that the reform had a significant impact on educational attainment of both men and women. By design of our analysis, those who are younger in a particular survey year are more likely to have been exposed to the 
reform and those who are older. If health behaviors change with age for reasons unrelated to education, it would be difficult to separate the impact of education from that of aging. However, because we employ three waves of the same survey, registered in 2008, 2010 and 2012, the age effect can be separated out from the cohort effect. ${ }^{25}$

After controlling for region of residence, and linear and quadratic terms in age and in year-of-birth, we find that for women, an increase in education, triggered by the reform, has no impact on self-reported health, BMI, overweight, obesity, or the consumption of cigarettes either at the extensive or intensive margin. Along the same lines, education does not influence women's daily consumption of fruits, vegetables, or the propensity to get a flu shot. Similar to the results for women, we find that in case of men, education has no impact on self-reported health, smoking, or the consumption of fruits, vegetables, or flu vaccinations. Education, however, increases men's BMI and the propensity to be overweight and obese.

The detrimental effect of education on BMI may stem from an impact of education on personal income. Akee et al. (2013) show that an increase in income, due to transfer payments, generated weight gain and obesity in adolescents and young adults among Native Americans from the Eastern Band of Cherokee, and that this effect is stronger for those who are from poor households. Our data do not contain information on personal income, but some family income indicators are provided. Controlling for family income and occupation does not change the results, although we cannot rule out the possibility that conditioning on carefully-measured personal income could have reduced the coefficient of education (Cutler and Lleras-Muney 2010).

\footnotetext{
${ }^{25}$ For example, somebody who is 25 years old in 2012 was born in 1987 (exposed to the reform), while the person who was 25 years old in 2010 was born in 1985 (not exposed to the reform). Thus, having access to three waves of the survey that covers a time span of 5 years (2008-2012) allows us to isolate the impact of age from the impact of treatment by the reform.
} 
A variety of robustness analyses do not alter the results. Similarly, accounting for antismoking campaigns initiated by the Turkish government in 2006 and accelerated in 2009 does not change the findings. We also find that the extent to which people believe in the effectiveness of the warning labels/signs placed on packs of cigarettes (Appendix Figure 1) are not impacted by people's educational attainment, or the interaction of education and smoking status.

These findings may be the result of the margin in which the education reform is implemented. The reform has increased compulsory schooling from 5 years (elementary school diploma) to 8 years (middle school diploma). While the extra three years of education would contribute to the development of cognitive and social skills, it can be argued that analytical and critical thinking skills would most be fostered by relatively rigorous math and science curriculum, which does not get introduced before the ninth grade. That is, as discussed by Clark and Royer (2013), the health returns to education can be larger for high school education and for college education. Other, more nuanced mechanisms are also possible. For example, more education may encourage relocation from rural areas to cities, which may cause dietary and lifestyle changes, such as easier access to fast food, calorie-rich soft drinks and a more sedentary lifestyle, which in turn may increase BMI (Popkin 2007). While our data set does not allow for an investigation of these and other potential mechanisms, the end result is that education has no impact of smoking, BMI or the consumption of health inputs for women in this developing country. The same is true for men, with the exception that men's education has a detrimental impact on BMI. 
Figure 1

Female Middle School Graduation Rate by Cohort

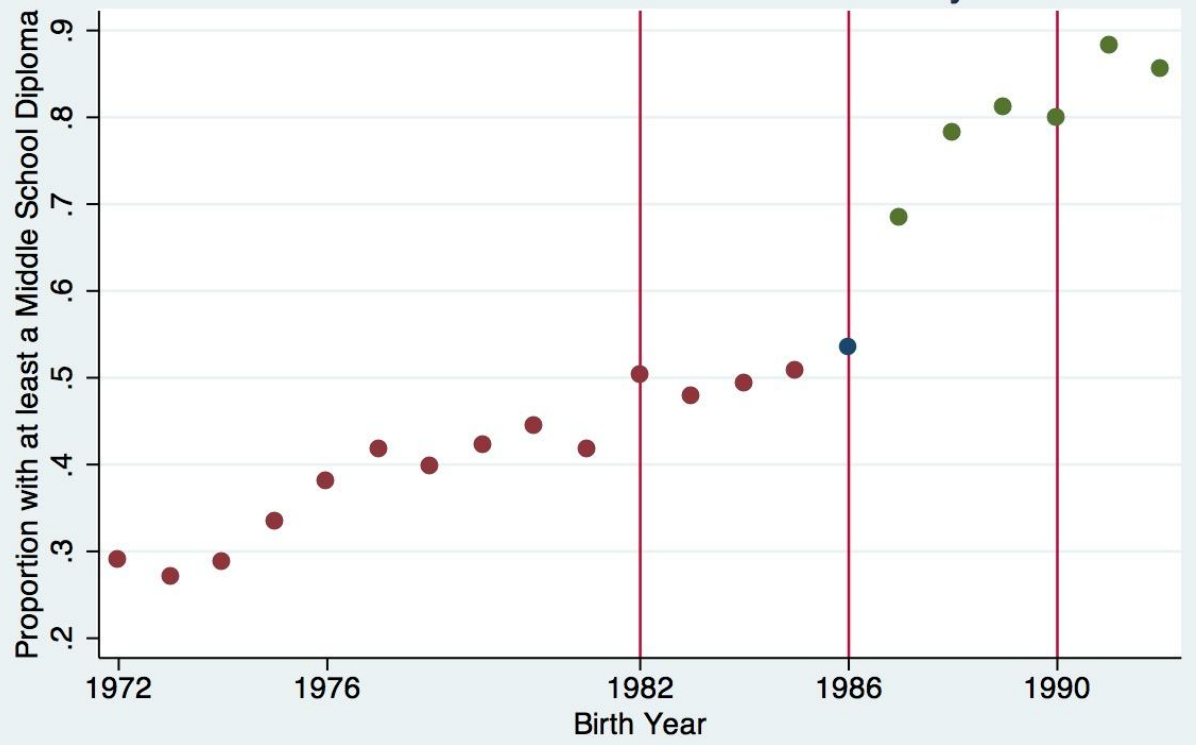

Figure 2

Male Middle Schol Graduation Rate by Cohort

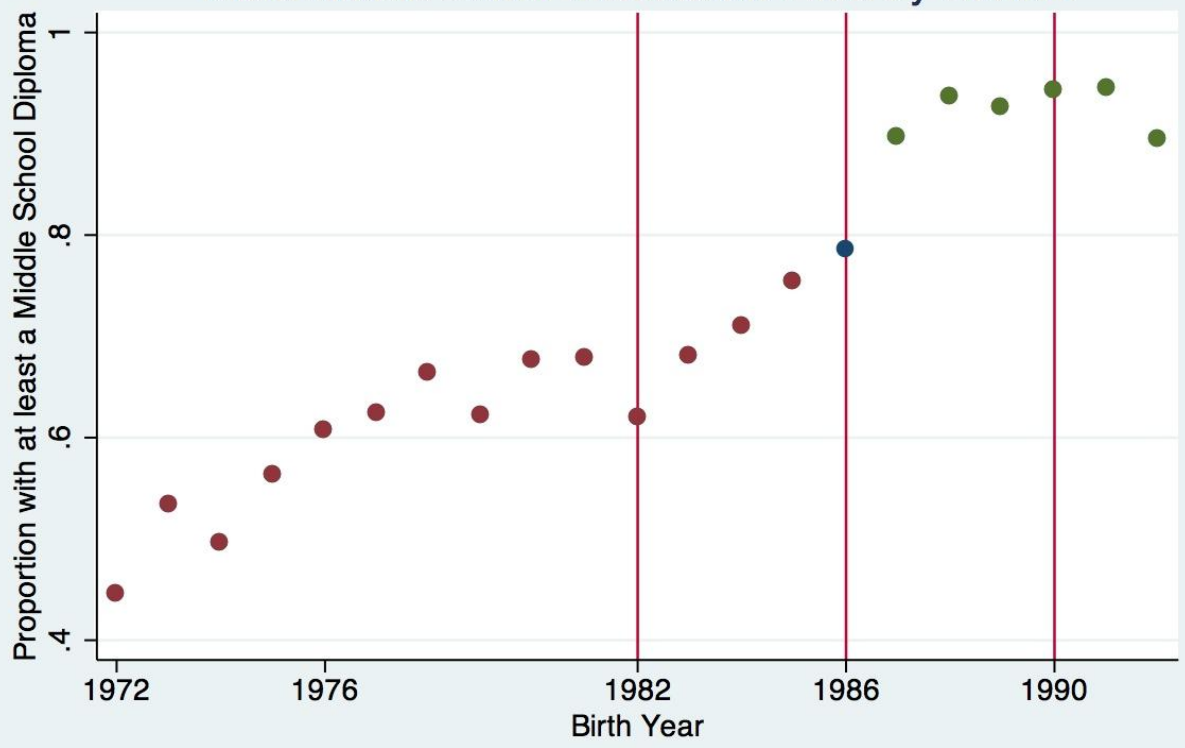


Figure 3

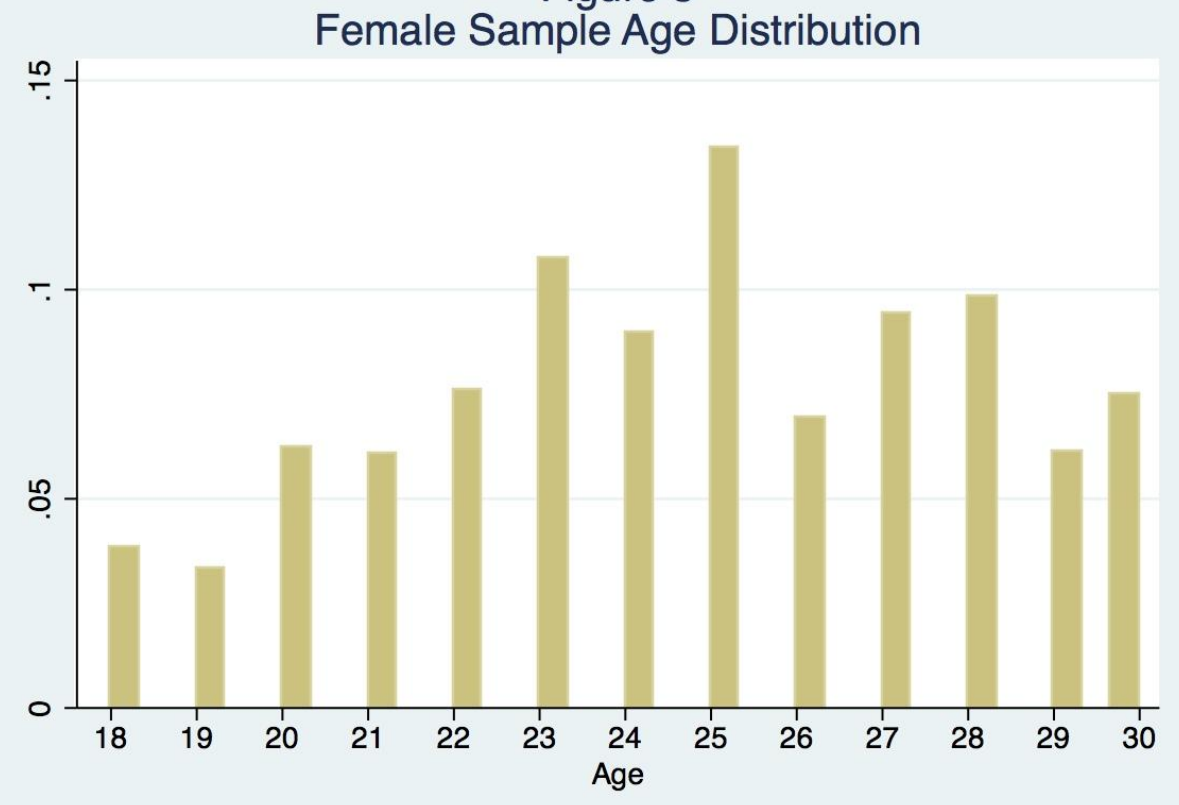

Figure 4

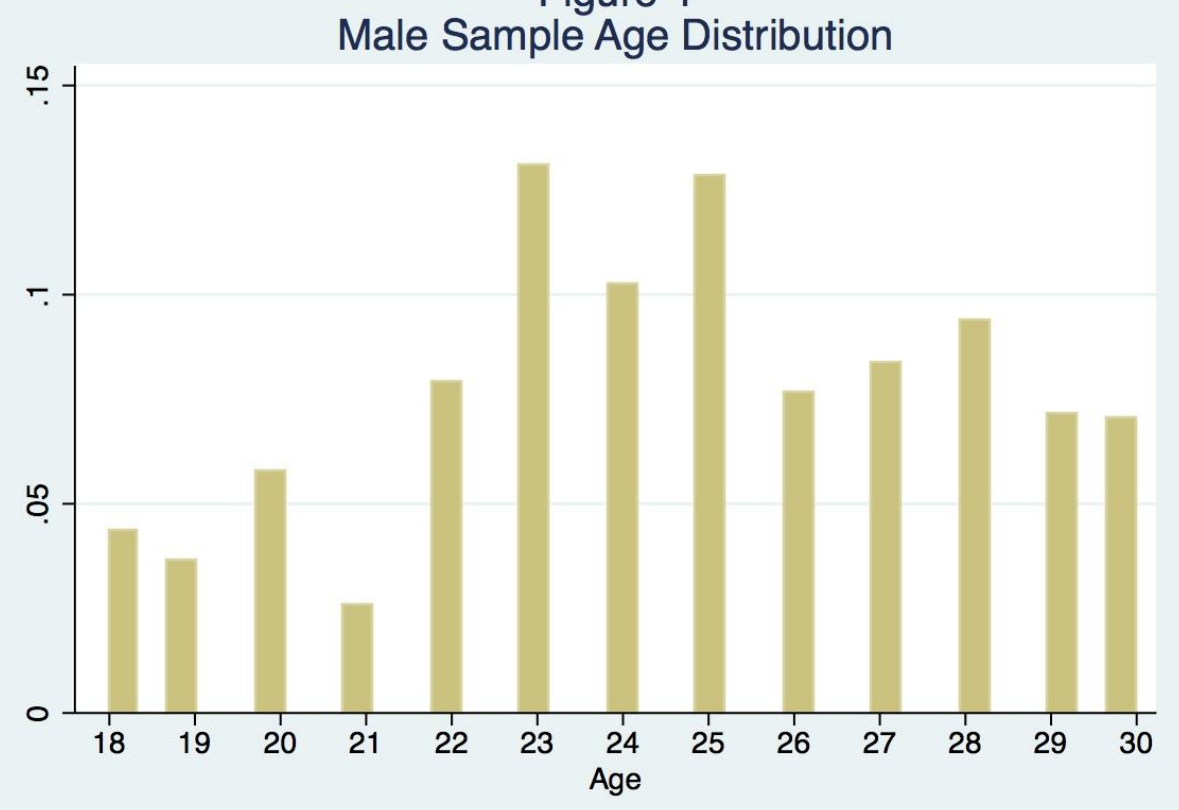


Table 1

Descriptive Statistics

\begin{tabular}{|c|c|c|c|c|c|c|c|}
\hline \multirow[b]{3}{*}{ Variable Name } & \multirow[b]{3}{*}{ Variable Descriptions } & \multirow{2}{*}{\multicolumn{3}{|c|}{$\begin{array}{l}(2) \\
\text { Males } \\
\end{array}$}} & \multirow{2}{*}{\multicolumn{3}{|c|}{$\begin{array}{l}\text { Females } \\
\text { Fem }\end{array}$}} \\
\hline & & & & & & & \\
\hline & & All & Control & Treatment & All & Control & Treatment \\
\hline \multicolumn{8}{|c|}{ A. Descriptive Statistics for Self-Reported Health } \\
\hline Middle School & $\begin{array}{l}=1 \text { if completed middle } \\
\text { school, }=0 \text { otherwise }\end{array}$ & $\begin{array}{c}0.80 \\
(0.40)\end{array}$ & $\begin{array}{c}0.69 \\
(0.46)\end{array}$ & $\begin{array}{c}0.93 \\
(0.26)\end{array}$ & $\begin{array}{c}0.63 \\
(0.48)\end{array}$ & $\begin{array}{c}0.50 \\
(0.50)\end{array}$ & $\begin{array}{c}0.77 \\
(0.42)\end{array}$ \\
\hline Good Health & $\begin{array}{l}=1 \text { if health is good or } \\
=0 \text { otherwise }\end{array}$ & $\begin{array}{c}0.88 \\
(0.33)\end{array}$ & $\begin{array}{c}0.88 \\
(0.32)\end{array}$ & $\begin{array}{c}0.87 \\
(0.33)\end{array}$ & $\begin{array}{c}0.82 \\
(0.39)\end{array}$ & $\begin{array}{c}0.80 \\
(0.40)\end{array}$ & $\begin{array}{c}0.84 \\
(0.37)\end{array}$ \\
\hline \multicolumn{2}{|c|}{ Number of Observations } & 3,530 & 1,889 & 1,641 & 4,614 & 2,465 & 2,149 \\
\hline \multicolumn{8}{|c|}{ B. Descriptive Statistics for Body Weight Measures } \\
\hline Middle School & $\begin{array}{l}=1 \text { if completed middle } \\
\text { school, }=0 \text { otherwise }\end{array}$ & 0.80 & 0.69 & 0.93 & 0.67 & 0.53 & 0.81 \\
\hline & & $(0.40)$ & $(0.46)$ & $(0.26)$ & $(0.47)$ & $(0.50)$ & (0.39) \\
\hline BMI & Body Mass Index & $\begin{array}{l}23.89 \\
(3.44)\end{array}$ & $\begin{array}{l}24.45 \\
(3.46)\end{array}$ & $\begin{array}{l}23.22 \\
(3.30)\end{array}$ & $\begin{array}{l}23.01 \\
(4.02)\end{array}$ & $\begin{array}{l}23.58 \\
(4.04)\end{array}$ & $\begin{array}{l}22.41 \\
(3.92)\end{array}$ \\
\hline Underweight & $\begin{array}{l}=1 \text { if } \mathrm{BMI}<18.5, \\
=0 \text { otherwise }\end{array}$ & $\begin{array}{c}0.03 \\
(0.18)\end{array}$ & $\begin{array}{c}0.02 \\
(0.14)\end{array}$ & $\begin{array}{c}0.05 \\
(0.22)\end{array}$ & $\begin{array}{l}0.09 \\
(0.29)\end{array}$ & $\begin{array}{l}0.07 \\
(0.25)\end{array}$ & $\begin{array}{c}0.12 \\
(0.32)\end{array}$ \\
\hline Overweight/Obese & $\begin{array}{l}=1 \text { if } \mathrm{BMI}>=25, \\
=0 \text { otherwise }\end{array}$ & $\begin{array}{c}0.32 \\
(0.47)\end{array}$ & $\begin{array}{c}0.39 \\
(0.49)\end{array}$ & $\begin{array}{c}0.24 \\
(0.43)\end{array}$ & $\begin{array}{c}0.26 \\
(0.44)\end{array}$ & $\begin{array}{c}0.32 \\
(0.47)\end{array}$ & $\begin{array}{c}0.19 \\
(0.39)\end{array}$ \\
\hline Obese & $\begin{array}{l}=1 \text { if } \mathrm{BMI}>=30, \\
=0 \text { otherwise }\end{array}$ & $\begin{array}{c}0.05 \\
(0.22)\end{array}$ & $\begin{array}{c}0.06 \\
(0.24)\end{array}$ & $\begin{array}{c}0.04 \\
(0.19)\end{array}$ & $\begin{array}{l}0.06 \\
(0.25)\end{array}$ & $\begin{array}{c}0.07 \\
(0.26)\end{array}$ & $\begin{array}{c}0.05 \\
(0.23)\end{array}$ \\
\hline Age & Age in years & $\begin{array}{l}24.29 \\
(3.18)\end{array}$ & $\begin{array}{l}26.54 \\
(1.99)\end{array}$ & $\begin{array}{l}21.65 \\
(2.11)\end{array}$ & $\begin{array}{l}24.20 \\
(3.18)\end{array}$ & $\begin{array}{l}26.61 \\
(1.98)\end{array}$ & $\begin{array}{l}21.63 \\
(1.99)\end{array}$ \\
\hline \multicolumn{2}{|c|}{ Number of Observations } & 3,383 & 1,833 & 1,550 & 4,136 & 2,218 & 1,918 \\
\hline \multicolumn{8}{|c|}{ C. Descriptive Statistics for Smoking Indicators } \\
\hline Middle School & $\begin{array}{l}=1 \text { if completed middle } \\
\text { school, = } 0 \text { otherwise }\end{array}$ & $\begin{array}{c}0.82 \\
(0.39)\end{array}$ & $\begin{array}{c}0.72 \\
(0.45)\end{array}$ & $\begin{array}{c}0.93 \\
(0.26)\end{array}$ & $\begin{array}{c}0.65 \\
(0.48)\end{array}$ & $\begin{array}{c}0.53 \\
(0.50)\end{array}$ & $\begin{array}{c}0.79 \\
(0.41)\end{array}$ \\
\hline Ever Smoked & $\begin{array}{l}=1 \text { if ever smoked } \\
\text { regularly, }=0 \text { otherwise }\end{array}$ & $\begin{array}{c}0.51 \\
(0.50)\end{array}$ & $\begin{array}{c}0.55 \\
(0.50)\end{array}$ & $\begin{array}{c}0.47 \\
(0.50)\end{array}$ & $\begin{array}{c}0.17 \\
(0.37)\end{array}$ & $\begin{array}{c}0.21 \\
(0.41)\end{array}$ & $\begin{array}{c}0.11 \\
(0.32)\end{array}$ \\
\hline Current Smoker & $\begin{array}{l}=1 \text { if currently smokes, } \\
=0 \text { otherwise }\end{array}$ & $\begin{array}{c}0.49 \\
(0.50)\end{array}$ & $\begin{array}{c}0.51 \\
(0.50)\end{array}$ & $\begin{array}{c}0.47 \\
(0.50)\end{array}$ & $\begin{array}{c}0.16 \\
(0.37)\end{array}$ & $\begin{array}{c}0.20 \\
(0.40)\end{array}$ & $\begin{array}{c}0.13 \\
(0.34)\end{array}$ \\
\hline Smokes Every Day* & $\begin{array}{l}=1 \text { if smokes everyday } \\
=0 \text { otherwise }\end{array}$ & $\begin{array}{c}0.90 \\
(0.30)\end{array}$ & $\begin{array}{c}0.91 \\
(0.28)\end{array}$ & $\begin{array}{c}0.89 \\
(0.32)\end{array}$ & $\begin{array}{c}0.76 \\
(0.43)\end{array}$ & $\begin{array}{c}0.78 \\
(0.41)\end{array}$ & $\begin{array}{c}0.73 \\
(0.45)\end{array}$ \\
\hline No. of Cigarettes* & $\begin{array}{l}\text { Number of Cigarettes } \\
\text { Smoked Per Day }\end{array}$ & $\begin{array}{l}12.07 \\
(9.76)\end{array}$ & $\begin{array}{l}12.35 \\
(9.79)\end{array}$ & $\begin{array}{l}11.74 \\
(9.72)\end{array}$ & $\begin{array}{c}8.74 \\
(7.65)\end{array}$ & $\begin{array}{c}8.93 \\
(7.50)\end{array}$ & $\begin{array}{c}8.39 \\
(7.90)\end{array}$ \\
\hline Age & Age in years & $\begin{array}{l}25.23 \\
(2.84)\end{array}$ & $\begin{array}{l}27.51 \\
(1.54)\end{array}$ & $\begin{array}{l}22.69 \\
(1.50)\end{array}$ & $\begin{array}{l}25.14 \\
(2.90)\end{array}$ & $\begin{array}{l}27.55 \\
(1.51)\end{array}$ & $\begin{array}{l}22.58 \\
(1.50)\end{array}$ \\
\hline Number of Observatic & & 2,566 & 1,360 & 1,206 & 3,323 & 1,816 & 1,507 \\
\hline
\end{tabular}

Standard deviations are in parentheses. The treatment group consists of those who were born in 1987-1990 and the treatment groups includes those born 1982-1985 constitute the control group.

(*) "Smokes Every Day" is conditional on being a current smoker and "No. of Cigarettes" is conditional on smoking every day; therefore, the associated samples sizes are smaller for these variables: ( $N=1293$ for males and $\mathrm{N}=572$ for females) for the Smokes Every Day; and ( $\mathrm{N}=1156$ for males and $\mathrm{N}=437$ for females) for No. of Cigarettes. 


\section{Table 2}

The Impact of Education on Health Outcomes OLS Estimates

\begin{tabular}{|c|c|c|c|c|c|}
\hline & $\begin{array}{c}\text { (1) } \\
\text { Good } \\
\text { Health }\end{array}$ & $\begin{array}{c}(2) \\
\text { BMI }\end{array}$ & $\begin{array}{c}\text { (3) } \\
\text { Underweight }\end{array}$ & $\begin{array}{c}(4) \\
\text { Overweight/ } \\
\text { Obese }\end{array}$ & $\begin{array}{c}(5) \\
\text { Obese }\end{array}$ \\
\hline \multicolumn{6}{|c|}{ Males } \\
\hline Middle School & $\begin{array}{c}0.102 * * * \\
(0.017)\end{array}$ & $\begin{array}{c}0.108 \\
(0.170)\end{array}$ & $\begin{array}{c}0.003 \\
(0.006)\end{array}$ & $\begin{array}{c}0.018 \\
(0.024)\end{array}$ & $\begin{array}{c}0.015 \\
(0.012)\end{array}$ \\
\hline Observations & 3,530 & 3,383 & 3,383 & 3,383 & 3,383 \\
\hline \multicolumn{6}{|c|}{ Females } \\
\hline Middle School & $\begin{array}{c}0.089 * * * \\
(0.015)\end{array}$ & $\begin{array}{c}-1.329 * * * \\
(0.166)\end{array}$ & $\begin{array}{c}0.047 * * * \\
(0.009)\end{array}$ & $\begin{array}{c}-0.133 * * * \\
(0.019)\end{array}$ & $\begin{array}{c}-0.040 * * * \\
(0.009)\end{array}$ \\
\hline Observations & 4,614 & 4,136 & 4,136 & 4,136 & 4,136 \\
\hline
\end{tabular}

Table 3

The Impact of Education on Smoking Outcomes OLS Estimates

(1)

(3)

Ever Smoked Current Smoker Smokes Every Day

\begin{tabular}{cccc}
\hline \multicolumn{5}{c}{ Males } & \\
\hline Middle School & -0.036 & $-0.066^{* *}$ & $-0.072^{* * *}$ \\
& $(0.024)$ & $(0.028)$ & $(0.025)$ \\
Observations & 2,566 & 2,566 & 2,566 \\
\hline Middle School & Females & & \\
\hline & $0.064^{* * *}$ & $0.047 * * *$ & $0.053^{* * *}$ \\
Observations & $(0.013)$ & $(0.014)$ & $(0.012)$ \\
\hline
\end{tabular}

Robust standard errors, corrected for clustering on region by year-of-birth, are in parentheses. *, **, and *** indicate statistical significance at the $10 \%, 5 \%$, and $1 \%$ levels, respectively. All models control region of residence fixed effects and linear and quadratic terms in age and in year-of-birth. 
Table 4

The Impact of Compulsory Schooling Reform on Having at least a Middle School Degree

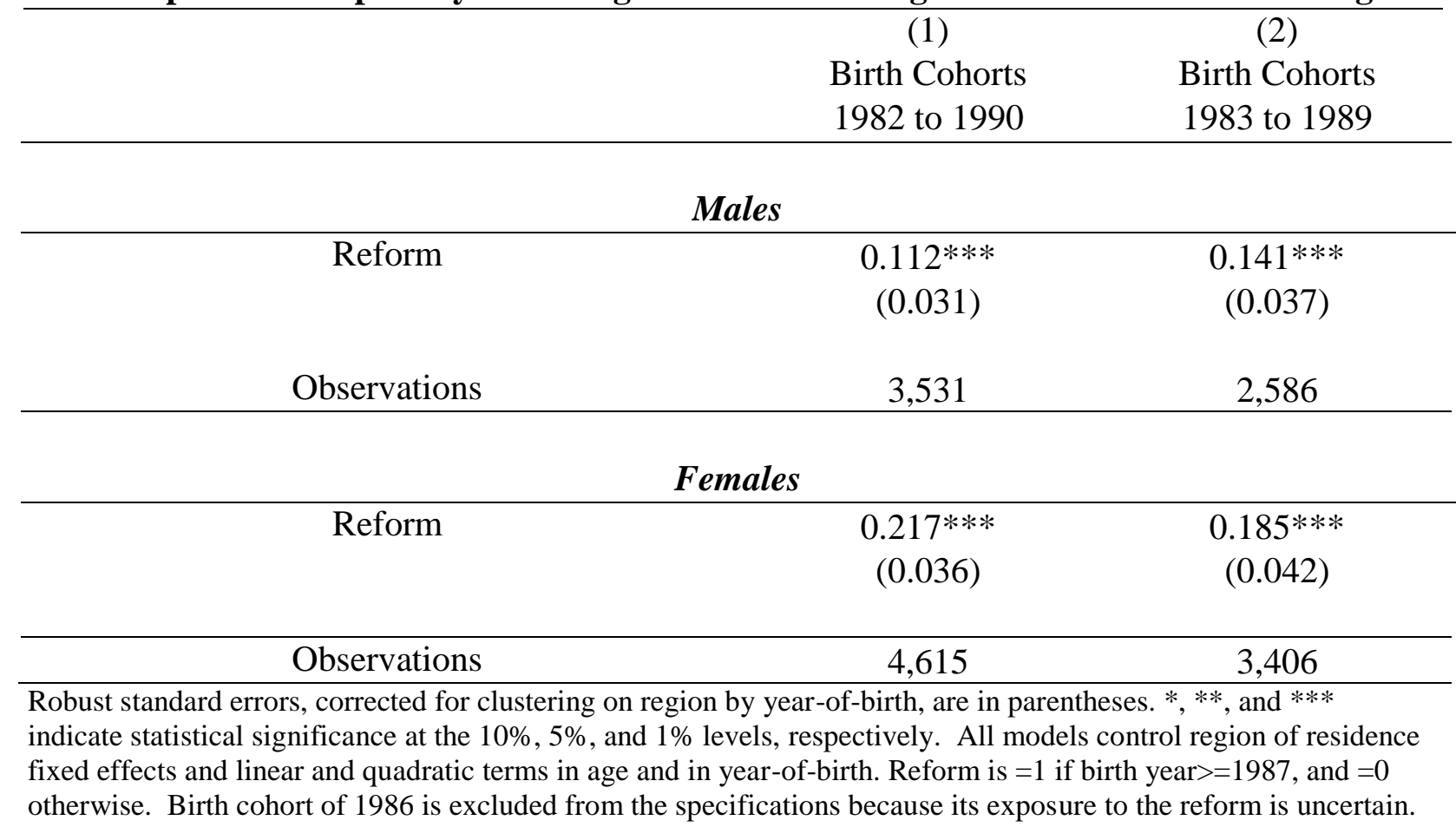




\section{Table 5}

The Impact of Education on Health Outcomes and Smoking Instrumental Variable Estimates

\begin{tabular}{|c|c|c|c|c|}
\hline Cohorts born in & $\begin{array}{c}(1) \\
1982 \text { to } \\
1990\end{array}$ & $\begin{array}{c}(2) \\
1983 \text { to } \\
1989\end{array}$ & $\begin{array}{c}(3) \\
1982 \text { to } \\
1990\end{array}$ & $\begin{array}{c}(4) \\
1983 \text { to } \\
1989\end{array}$ \\
\hline A. The Impact of Education on Self-Reported Health & \multicolumn{4}{|c|}{$\begin{array}{c}\text { Males } \\
\text { Females } \\
\text { ct of Education on Self-Reported Health }\end{array}$} \\
\hline $\begin{array}{l}\text { Dependent Variable } \\
\text { Good/Excellent Health }\end{array}$ & $\begin{array}{c}0.051 \\
(0.237)\end{array}$ & $\begin{array}{l}-0.087 \\
(0.239)\end{array}$ & $\begin{array}{c}0.034 \\
(0.116)\end{array}$ & $\begin{array}{c}0.138 \\
(0.160)\end{array}$ \\
\hline $\begin{array}{l}\text { First Stage F-test } \\
\text { Observations }\end{array}$ & $\begin{array}{l}12.39 \\
3,530\end{array}$ & $\begin{array}{l}14.49 \\
2,585\end{array}$ & $\begin{array}{l}36.36 \\
4,614\end{array}$ & $\begin{array}{l}19.18 \\
3,405\end{array}$ \\
\hline \multicolumn{5}{|c|}{$\begin{array}{c}B_{i} \text { The Impact of Education on Body Weight } \\
\end{array}$} \\
\hline$B M I$ & $\begin{array}{l}7.075^{* *} \\
(3.311)\end{array}$ & $\begin{array}{l}7.470 * * \\
(2.973)\end{array}$ & $\begin{array}{c}0.557 \\
(1.539)\end{array}$ & $\begin{array}{c}0.861 \\
(2.128)\end{array}$ \\
\hline Underweight & $\begin{array}{l}-0.109 \\
(0.136)\end{array}$ & $\begin{array}{l}-0.050 \\
(0.107)\end{array}$ & $\begin{array}{l}-0.108 \\
(0.093)\end{array}$ & $\begin{array}{l}-0.229^{*} \\
(0.134)\end{array}$ \\
\hline Overweight/Obese & $\begin{array}{l}0.696^{*} \\
(0.406)\end{array}$ & $\begin{array}{c}0.727 * * \\
(0.336)\end{array}$ & $\begin{array}{l}-0.101 \\
(0.161)\end{array}$ & $\begin{array}{l}-0.114 \\
(0.223)\end{array}$ \\
\hline Obese & $\begin{array}{l}0.354^{*} \\
(0.198)\end{array}$ & $\begin{array}{c}0.459 * * \\
(0.196)\end{array}$ & $\begin{array}{c}0.081 \\
(0.076)\end{array}$ & $\begin{array}{c}0.107 \\
(0.111)\end{array}$ \\
\hline First Stage F-test & 12.35 & 16.76 & 38.97 & 19.75 \\
\hline Observations & 3,383 & 2,484 & 4,136 & 3,066 \\
\hline \multicolumn{5}{|c|}{$C$ The Impact of Education on Smoking } \\
\hline Ever Smoked & $\begin{array}{c}0.193 \\
(0.396)\end{array}$ & $\begin{array}{l}-0.202 \\
(0.284)\end{array}$ & $\begin{array}{l}-0.024 \\
(0.105)\end{array}$ & $\begin{array}{c}0.048 \\
(0.126)\end{array}$ \\
\hline Current Smoker & $\begin{array}{c}0.439 \\
(0.412)\end{array}$ & $\begin{array}{l}-0.163 \\
(0.285)\end{array}$ & $\begin{array}{l}-0.008 \\
(0.117)\end{array}$ & $\begin{array}{c}0.059 \\
(0.144)\end{array}$ \\
\hline First Stage F-test & 8.480 & 15.64 & 53.23 & 33.51 \\
\hline Observations & 2,566 & 1,924 & 3,323 & 2,479 \\
\hline Smokes Every Day & $\begin{array}{c}0.027 \\
(0.488)\end{array}$ & $\begin{array}{l}-0.118 \\
(0.567)\end{array}$ & $\begin{array}{l}-0.343 \\
(0.492)\end{array}$ & $\begin{array}{l}-0.629 \\
(0.527)\end{array}$ \\
\hline First Stage F-test & 5.828 & 4.738 & 6.423 & 4.370 \\
\hline Observations & 1,293 & 956 & 572 & 435 \\
\hline No. of Cigarettes & $\begin{array}{l}-11.566 \\
(15.504)\end{array}$ & $\begin{array}{c}-6.949 \\
(18.733)\end{array}$ & $\begin{array}{l}-1.468 \\
(13.685)\end{array}$ & $\begin{array}{c}8.163 \\
(17.349)\end{array}$ \\
\hline $\begin{array}{l}\text { First Stage F-test } \\
\text { Observations }\end{array}$ & $\begin{array}{l}6.369 \\
1,156\end{array}$ & $\begin{array}{c}4.356 \\
856\end{array}$ & $\begin{array}{c}1.977 \\
437\end{array}$ & $\begin{array}{c}1.841 \\
328\end{array}$ \\
\hline
\end{tabular}

The entries are the instrumental-variables coefficients of having at least a middle school education. Dependent variables are listed on each row. Robust standard errors, corrected for clustering on region by year-of-birth, are in parentheses. *, **, and *** indicate statistical significance at the 10\%, 5\%, and 1\% levels, respectively. All models control region of residence fixed effects and linear and quadratic terms in age and in year-of-birth. 


\section{Table 6}

The Impact of Education Reform on Health Outcomes and Smoking Reduced Form Estimates

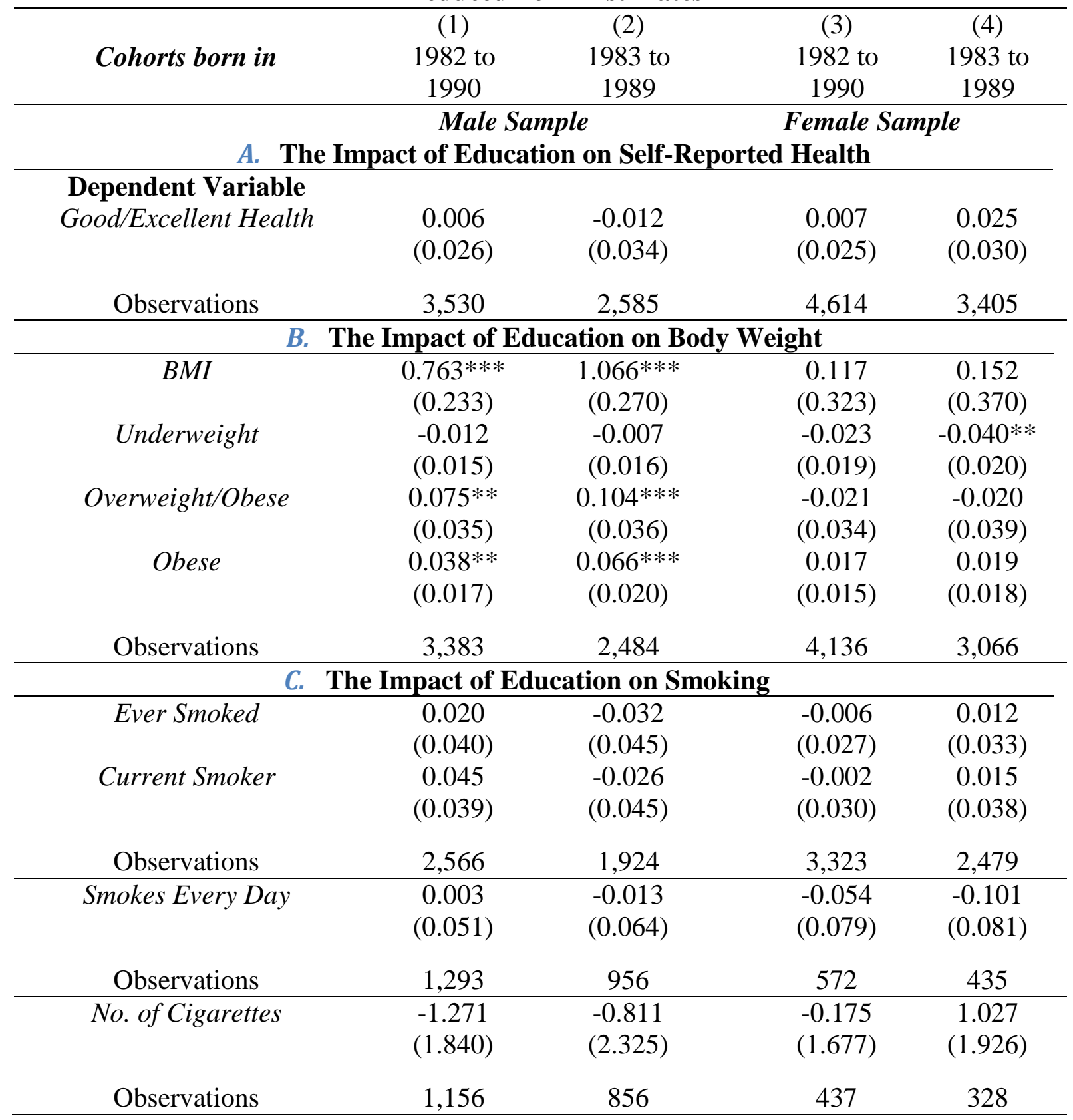

The entries are the reduced-form estimates of the impact of exposure to the reform. Robust standard errors, corrected for clustering on region by year-of-birth, are in parentheses. *, **, and *** indicate statistical significance at the $10 \%, 5 \%$, and $1 \%$ levels, respectively. All models control region of residence fixed effects and linear and quadratic terms in age and in year-of-birth. 
Table 7

The Impact of Education on Health Inputs

Instrumental Variable Estimates

\begin{tabular}{|c|c|c|c|c|}
\hline Cohorts born in & $\begin{array}{c}(2) \\
1982 \text { to } \\
1990\end{array}$ & $\begin{array}{c}(3) \\
1983 \text { to } \\
1989\end{array}$ & $\begin{array}{c}(5) \\
1982 \text { to } \\
1990\end{array}$ & $\begin{array}{c}(6) \\
1983 \text { to } \\
1989\end{array}$ \\
\hline & \multicolumn{2}{|c|}{ Males } & \multicolumn{2}{|c|}{ Females } \\
\hline \multicolumn{5}{|c|}{ Daily Fruit Consumption } \\
\hline Middle School & $\begin{array}{l}-0.088 \\
(0.300)\end{array}$ & $\begin{array}{l}-0.292 \\
(0.297)\end{array}$ & $\begin{array}{l}-0.070 \\
(0.133)\end{array}$ & $\begin{array}{c}0.048 \\
(0.171)\end{array}$ \\
\hline $\begin{array}{c}\text { First Stage F-test } \\
\text { Observations }\end{array}$ & $\begin{array}{l}12.95 \\
3,526\end{array}$ & $\begin{array}{l}14.98 \\
2,581\end{array}$ & $\begin{array}{l}36.05 \\
4,605\end{array}$ & $\begin{array}{l}19.29 \\
3,399\end{array}$ \\
\hline \multicolumn{5}{|c|}{ Daily Vegetable Consumption } \\
\hline Middle School & $\begin{array}{c}-0.289 \\
(0.356)\end{array}$ & $\begin{array}{c}-0.233 \\
(0.368)\end{array}$ & $\begin{array}{c}-0.101 \\
(0.146)\end{array}$ & $\begin{array}{c}-0.033 \\
(0.219)\end{array}$ \\
\hline First Stage F-test & 12.7 & 14.74 & 37.04 & 19.84 \\
\hline Observations & 3,526 & 2,581 & 4,607 & 3,400 \\
\hline \multicolumn{5}{|c|}{ Flu Shot-Ever } \\
\hline Middle School & $\begin{array}{l}-0.119 \\
(0.241)\end{array}$ & $\begin{array}{l}-0.003 \\
(0.255)\end{array}$ & $\begin{array}{c}0.135 \\
(0.103)\end{array}$ & $\begin{array}{c}0.121 \\
(0.168)\end{array}$ \\
\hline $\begin{array}{c}\text { First Stage F-test } \\
\text { Observations }\end{array}$ & $\begin{array}{l}13.14 \\
3.496\end{array}$ & $\begin{array}{l}14.89 \\
2559\end{array}$ & $\begin{array}{l}36.40 \\
4.589\end{array}$ & $\begin{array}{l}19.39 \\
3385\end{array}$ \\
\hline \multicolumn{5}{|c|}{ Flu Shot- Last 2 Years } \\
\hline Middle School & $\begin{array}{l}-0.142 \\
(0.145)\end{array}$ & $\begin{array}{l}-0.156 \\
(0.153)\end{array}$ & $\begin{array}{c}0.065 \\
(0.065)\end{array}$ & $\begin{array}{c}0.047 \\
(0.112)\end{array}$ \\
\hline First Stage F-test & 13.56 & 16.09 & 35.36 & 18.89 \\
\hline Observations & 3,497 & 2,557 & 4,585 & 3,3391 \\
\hline
\end{tabular}

The entries are the instrumental-variables coefficients of having at least a middle school education. Robust standard errors, corrected for clustering on region by year-of-birth, are in parentheses. *, **, and $* * *$ indicate statistical significance at the $10 \%, 5 \%$, and $1 \%$ levels, respectively. All models control region of residence fixed effects and linear and quadratic terms in age and in year-of-birth. 
Table 8

The Impact of Education on Health Outcomes and Smoking

Below Median Income Sample

Instrumental Variable Estimates

\begin{tabular}{|c|c|c|c|c|}
\hline Cohorts born in & $\begin{array}{c}(1) \\
1982 \text { to } \\
1990 \\
\end{array}$ & $\begin{array}{c}(2) \\
1983 \text { to } \\
1989 \\
\end{array}$ & $\begin{array}{c}(3) \\
1982 \text { to } \\
1990 \\
\end{array}$ & $\begin{array}{c}(4) \\
1983 \text { to } \\
1989 \\
\end{array}$ \\
\hline A. $\mathbf{T}$ & \multicolumn{2}{|c|}{ Males } & \multicolumn{2}{|c|}{ Females } \\
\hline $\begin{array}{l}\text { Dependent Variable } \\
\text { Good/Excellent Health }\end{array}$ & $\begin{array}{c}0.157 \\
(0.230)\end{array}$ & $\begin{array}{c}0.061 \\
(0.217)\end{array}$ & $\begin{array}{c}0.041 \\
(0.140)\end{array}$ & $\begin{array}{c}0.162 \\
(0.194)\end{array}$ \\
\hline $\begin{array}{c}\text { First Stage F-test } \\
\text { Observations }\end{array}$ & $\begin{array}{l}14.30 \\
1,710 \\
\end{array}$ & $\begin{array}{l}17.44 \\
1,200 \\
\end{array}$ & $\begin{array}{l}33.64 \\
2,541\end{array}$ & $\begin{array}{l}20.29 \\
1,848 \\
\end{array}$ \\
\hline \multicolumn{5}{|c|}{ B. The Impact of Education on Body Weight } \\
\hline$B M I$ & $\begin{array}{l}3.337 * * \\
(1.566)\end{array}$ & $\begin{array}{l}3.192 * * \\
(1.420)\end{array}$ & $\begin{array}{l}-0.311 \\
(1.370)\end{array}$ & $\begin{array}{l}-0.750 \\
(1.827)\end{array}$ \\
\hline Underweight & $\begin{array}{l}-0.062 \\
(0.107)\end{array}$ & $\begin{array}{l}-0.111 \\
(0.089)\end{array}$ & $\begin{array}{l}-0.043 \\
(0.072)\end{array}$ & $\begin{array}{c}0.007 \\
(0.086)\end{array}$ \\
\hline Overweight/Obese & $\begin{array}{c}0.573 * * \\
(0.234)\end{array}$ & $\begin{array}{c}0.455^{* *} \\
(0.200)\end{array}$ & $\begin{array}{l}-0.143 \\
(0.147)\end{array}$ & $\begin{array}{l}-0.161 \\
(0.191)\end{array}$ \\
\hline Obese & $\begin{array}{l}0.237 * \\
(0.128)\end{array}$ & $\begin{array}{c}0.216^{* *} \\
(0.109)\end{array}$ & $\begin{array}{c}0.004 \\
(0.082)\end{array}$ & $\begin{array}{c}0.061 \\
(0.118)\end{array}$ \\
\hline $\begin{array}{c}\text { First Stage F-test } \\
\text { Observations }\end{array}$ & $\begin{array}{l}14.06 \\
1,614\end{array}$ & $\begin{array}{l}19.39 \\
1,138\end{array}$ & $\begin{array}{l}37.58 \\
2,184\end{array}$ & $\begin{array}{l}23.89 \\
1,592\end{array}$ \\
\hline \multicolumn{5}{|c|}{ C. The Impact of Education on Smoking } \\
\hline Ever Smoked & $\begin{array}{c}0.273 \\
(0.298)\end{array}$ & $\begin{array}{c}0.347 \\
(0.253)\end{array}$ & $\begin{array}{l}-0.034 \\
(0.118)\end{array}$ & $\begin{array}{l}-0.016 \\
(0.139)\end{array}$ \\
\hline Current Smoker & $\begin{array}{c}0.367 \\
(0.266)\end{array}$ & $\begin{array}{c}0.250 \\
(0.211)\end{array}$ & $\begin{array}{l}-0.069 \\
(0.114)\end{array}$ & $\begin{array}{l}-0.042 \\
(0.132)\end{array}$ \\
\hline $\begin{array}{c}\text { First Stage F-test } \\
\text { Observations }\end{array}$ & $\begin{array}{l}14.25 \\
1,091\end{array}$ & $\begin{array}{c}23.36 \\
785\end{array}$ & $\begin{array}{l}47.23 \\
1,640\end{array}$ & $\begin{array}{l}39.64 \\
1,222\end{array}$ \\
\hline Smokes Every Day & $\begin{array}{c}0.158 \\
(0.268)\end{array}$ & $\begin{array}{c}0.355 \\
(0.272)\end{array}$ & $\begin{array}{l}-1.411 \\
(1.641)\end{array}$ & $\begin{array}{l}-1.973 \\
(1.987)\end{array}$ \\
\hline First Stage F-test & 10.60 & 12.13 & 1.038 & 1.149 \\
\hline Observations & 539 & 394 & 264 & 200 \\
\hline No. of Cigarettes & $\begin{array}{c}-0.903 \\
(12.283)\end{array}$ & $\begin{array}{c}-3.112 \\
(12.622)\end{array}$ & $\begin{array}{l}-1,132.22 \\
(43,025.5)\end{array}$ & $\begin{array}{c}91.548 \\
(275.579)\end{array}$ \\
\hline $\begin{array}{c}\text { First Stage F-test } \\
\text { Observations }\end{array}$ & $\begin{array}{c}11.06 \\
476\end{array}$ & $\begin{array}{c}11.16 \\
347\end{array}$ & $\begin{array}{c}0.000629 \\
195\end{array}$ & $\begin{array}{c}0.106 \\
147\end{array}$ \\
\hline
\end{tabular}

The entries are the instrumental-variables coefficients of having at least a middle school education. The dependent variables are listed on each row. Robust standard errors, corrected for clustering on region by year-of-birth level are in parentheses. *, **, and $* * *$ indicate statistical significance at the $10 \%, 5 \%$, and $1 \%$ levels, respectively. All models control region of residence fixed effects and linear and quadratic terms in age and in year-of-birth. 


\section{References}

Acemoglu, Daron, and Simon Johnson, 2007. "Disease and Development: The Effect of Life Expectancy on Economic Growth." Journal of Political Economy, 115(6): 925.

Adda, Jérôme, James Banks and Hans-Martin Gaudecker, 2009. "The Impact of Income Shocks on Health: Evidence from Cohort Data." Journal of the European Economic Association 7(6): 1361-1399.

Aguiero, Jorge M., and Prashant Bharadwaj, 2014. "Do the More Educated Know More about Health? Evidence from Schooling and HIV Knowledge in Zimbabwe." Economic Development and Cultural Change, Vol. 62(3): 489-517

Aizer, Anna, and Laura Stroud, 2010. "Education, Knowledge and the evolution of Disparities in Health.” NBER Working Paper No: 15840.

Akee, Randall, Emilia Simeonova, William Copeland, Adrian Angold and Jane Costello, 2013. "Does More Money Make You Fat? The Effect of Household Income Transfers on Adolescent and Young Adult Health. American Economic Journal: Applied Economics.

Albouy, Valerie, and Laurent Lequien, 2009. "Does Compulsory Education Lower Mortality?" Journal of Health Economics 28(1): 155-68.

Altindag, Duha, Colin Cannonier, and Naci Mocan, 2011. "The impact of education on health knowledge." Economics of Education Review 30(5): 792-812.

Ashraf, Q. H., A. Lester, and D. N. Weil. 2009. "When does Improving Health Raise GDP?" NBER Macroeconomics Annual 23: 157-204.

Barro, Robert and Jong-Wha Lee, 2013. "A New Data Set of Educational Attainment in the World, 1950-2010." Journal of Development Economics, Vol 104, pp.184-198.

Bleakley, Hoyt. 2007. "Disease and development: Evidence from Hookworm Eradication in the American South." Quarterly Journal of Economics 122(1): 73.

Boyce, Christopher and Andrew Oswald, 2012." Do People Become Healthier After Being Promoted?" Health Economics. 21" 580-96.

Brunello, Giorgio, Daniele Fabbri, and Margherita Fort, 2013. "The Causal Effect of Education on Body Mass: Evidence from Europe," Journal of Labor Economics, Vol. 31(1): 195 - 223.

Burkhauser, Richard and John Cawley, 2008. "Beyond BMI: The Value of More Accurate Measures of Fatness and Obesity in Social Science Research," Journal of Health Economics, 27: 519-29. 
Cannonier, Colin and Naci Mocan, 2104.' Empowering Women through Education: Evidence from Sierra Leone," NBER Working Paper No: 18016.

Card, D. 2001. "Estimating the Return to Schooling: Progress on Some Persistent Econometric Problems." Econometrica, 69(5), pp. 1127-60.

Cawley, John, John Moran and Kosali Simon, 2010." The impact of Income on the Weight of Elderly Americans." Health Economics, 19: 979-93.

Cesur, R. and Naci Mocan, 2013. "Does Secular Education Impact Religiosity, Electoral Participation and the Propensity to Vote for Islamic Parties? Evidence from an Education Reform in a Muslim Country." NBER Working Paper, No. 19769.

Chou, Shin-Yi, Jin-Tan Liu, Michael Grossman, Ted Joyce, 2010. "Parental Education and Child Health: Evidence from a Natural Experiment in Taiwan," American Economic Journal: Applied Economics, Vol. 2(1): 33-61.

Clark, Damon, and Heather Royer, 2013. "The Effect of Education on Adult Mortality and Health: Evidence from Britain.” American Economic Review, 103(6): 2087-2120

Currie, Janet and Enrico Moretti, 2003. "Mother's Education and the Intergenerational Transmission of Human Capital: Evidence from College Openings." Quarterly Journal of Economics 118(4): 1495-1532.

Cutler, David M. and Adriana Lleras-Muney, 2010. "Understanding Differences in Health Behaviors by education." Journal of Health Economics 29(1): 1-28.

De Walque, Damien. 2007. "Does education Affect smoking Behaviors?: Evidence Using the Vietnam draft as an Instrument for College Education." Journal of Health Economics 26( 5): 877-895.

Dinçer, Mehmet A., Neeraj Kaushal, and Michael Grossman, 2014. "Women's Education: Harbinger of Another Spring? Evidence from a Natural Experiment in Turkey." World Development, 64, pp. 243-58.

Dulger, I, 2004. "Turkey: Rapid coverage for compulsory education - the 1997 basic education program.” Shanghai. World Bank Conference, Scaling Up Poverty Reduction: A Global Learning Process.

Grossman, Michael, 1972a. "On the Concept of Health Capital and the Demand for Health." Journal of Political Economy, 80(2): 223-255.

Grossman, Michael. 1972b. The Demand for Health: A theoretical and Empirical Investigation. New York: Columbia University Press for the National Bureau of Economic research 
Güneş, Pınar Mine, 2013. "The Impact of Female Education on Fertility: Evidence from Turkey.” Grand Challenges Canada Working Paper, GCC 13-01.

Kempter, D., H. Juerges and S. Reinhold, 2011. "Changes in Compulsory Schooling and the Causal Effect of Education on Health: Evidence from Germany", Journal of Health Economics 30(2):340-354.

Kirdar, Murat, Meltem Dayioglu and Ismet Koc, 2014.” Does Longer Compulsory Education Equalize Schooling by Gender and Rural/Urban Residence?” IZA Working Paper No: 7939.

Lindeboom, Maarten, Ana Llena-Nozal, and Bas van Der Klaauw, 2009. "Parental Education and Child Health: Evidence from a Schooling Reform." Journal of Health Economics 28(1): 109-131

Lleras-Muney, Adriana. 2005. "The Relationship Between Education and Adult Mortality in the United States.” Review of Economic Studies 72: 189-221.

Lorentzen, Peter, John McMillan, and Romain Wacziarg, 2008. "Death and Development." Journal of Economic Growth 13(2): 81-124.

Mathios, Alan, 2000. "The Impact of Mandatory Disclosure Laws on Product Choices: An Analysis of the Salad Dressing Market." The Journal of Law and Economics 43(2): 651-678.

McCrary, Justin, and Heather Royer. 2011. "The Effect of Female Education on Fertility and Infant Health: Evidence from School Entry Policies Using Exact Date of Birth." American Economic Review, 101(1): 158-95.

Meghir, Costas, Mårten Palme, and Emilia Simeonova. 2012. "Education, health and mortality: Evidence from a social experiment.” NBER Working Paper No: No. 17932.

Mocan, Leyla. 2014. "The Impact of Education on Wages: Analysis of an Education Reform in Turkey.” University of Pennsylvania, Wharton School of Business Working Paper.

Mokdad, Ali H., James S. Marks, Donna F. Stroup, and Julie L. Gerberding, 2004. "Actual Causes of Death in the United States, 2000." Journal of the American Medical Association, 291(10): 1238-1245.

Ng, Marie, Tom Fleming, Margaret Robinson, Blake Thomson, Nicholas Graetz, Christopher Margono, Erin C. Mullany et al. 2014."Global, regional, and national prevalence of Overweight and obesity in Children and Adults during 1980-2013: A Systematic Analysis for the Global Burden of Disease Study 2013." The Lancet.

Oreopoulos, Philip, 2006. "Estimating Average and Local Average Treatment Effects of Education when Compulsory Schooling Laws Really Matter," American Economic

Review. 96(1): 152-75. 
Osili, U., and B. Long, 2008. "Does Female Schooling Reduce fertility? Evidence from Nigeria." Journal of Development Economics 87(1), pp. 57-75.

Palme, Mårten and Emilia Simeonova, forthcoming, "Does Women’s Education Affect Breast Canver Risk and Survival? Evidence from a Population-Based Social Experiment in Education." Journal of Health Economics.

Popkin, Barry, Linda Adair, abd Shu Wen Ng, 2012." Global Nutrition Transition and the Pandemic of obesity in Developing Countries," Nutrition Reviews, 70(1): 3-21.

Popkin, Bary, 2007. “The World is Fat," Scientific American, 297(3): 88-95.

Price, Joseph, and Kosali Simon, 2009. "Patient Education and the Impact of New Medical Research." Journal of Health Economics 28(6): 1166-1174.

Schmeiser, Maximilian D, 2009. "Expanding Waistlines and Wallets: The Impact of Family Income on the BMI of Women and Men Eligible for the Earned Income Tax Credit." Health Economics 18 (11): 1277-1294.

Snyder, Stephen and William Evans, 2006."The effect of Income on Mortality: Evidence from the Social Security Notch.” Review of Economics and Statistics. 8893): 482-95.

Stephens, Melvin Jr. and Dou-Yan Yang, 2014. "Compulsory Education and the Benefits of Schooling." American Economic Review, 104(6): 1777-92.

Tansel, Aysit, and Deniz Karaoglan, 2014 "Health Behaviors and Education in Turkey." Koc University-TUSIAD Economic Research Forum Working Paper, No: 1414.

UNESCO (Paris). (2000). The Dakar Framework for Action: Education for All: Meeting Our Collective Commitments: Including Six Regional Frameworks for Action. UNESCO.

Yürekli A, Önder Z, Elibol M, Erk N, Cabuk A, Fisunoglu M, Erk SF, Chaloupka FJ. 2010. "The Economics of Tobacco and Tobacco Taxation inTurkey." Paris: International Union Against Tuberculosis and Lung Disease.

World Bank. 2011. "Learning for All: Investing in People's Knowledge and Skills to Promote Development." World Bank Group Education Strategy 2020. Washington, DC: World Bank.

World Health Organization. 2009. "2008-2013 Action Plan for the Global Strategy for the Prevention and Control of Non-Communicable Diseases: Prevent and Control Cardiovascular Diseases, Cancers, Chronic Respiratory Diseases and Diabetes.” Geneva: World Health Organization.

World Health Organization. 2010. "Global Status Report on Non-communicable Diseases 2010." Geneva: World Health Organization. 
World Health Organization. 2013. "WHO Report on the Global Tobacco Epidemic, 2013:

Enforcing Bans on Tobacco Advertising, Promotion and Sponsorship." Geneva: World Health Organization. 
Appendix Table A1

The Impact of Education on Health Outcomes and Smoking

Above Median Income Sample

Instrumental Variable Estimates

\begin{tabular}{|c|c|c|c|c|}
\hline Cohorts born in & $\begin{array}{c}\text { (1) } \\
1982 \text { to } \\
1990\end{array}$ & $\begin{array}{c}(2) \\
1983 \text { to } \\
1989\end{array}$ & $\begin{array}{c}(3) \\
1982 \text { to } \\
1990\end{array}$ & $\begin{array}{c}(4) \\
1983 \text { to } \\
1989\end{array}$ \\
\hline \multicolumn{5}{|c|}{$\begin{array}{l}\text { Males } \\
\text { The Impact of Education on Self-Reported Health }\end{array}$} \\
\hline $\begin{array}{l}\text { Dependent Variable } \\
\text { Good/Excellent Health }\end{array}$ & $\begin{array}{l}-0.149 \\
(0.611)\end{array}$ & $\begin{array}{l}-0.732 \\
(1.016)\end{array}$ & $\begin{array}{c}0.078 \\
(0.182)\end{array}$ & $\begin{array}{c}0.146 \\
(0.296)\end{array}$ \\
\hline $\begin{array}{l}\text { First Stage F-test } \\
\text { Observations }\end{array}$ & $\begin{array}{l}2.607 \\
1,785\end{array}$ & $\begin{array}{l}1.693 \\
1,363\end{array}$ & $\begin{array}{l}12.54 \\
2,021\end{array}$ & $\begin{array}{l}4.904 \\
1,522\end{array}$ \\
\hline \multicolumn{5}{|c|}{ The Impact of Education on Body Weight } \\
\hline$B M I$ & $\begin{array}{c}18.963 \\
(15.047)\end{array}$ & $\begin{array}{c}26.356 \\
(21.586)\end{array}$ & $\begin{array}{c}3.013 \\
(3.409)\end{array}$ & $\begin{array}{c}5.001 \\
(6.745)\end{array}$ \\
\hline Underweight & $\begin{array}{l}-0.268 \\
(0.437)\end{array}$ & $\begin{array}{c}0.355 \\
(0.539)\end{array}$ & $\begin{array}{l}-0.313 \\
(0.245)\end{array}$ & $\begin{array}{l}-0.955 \\
(0.696)\end{array}$ \\
\hline Overweight/Obese & $\begin{array}{c}0.847 \\
(1.432)\end{array}$ & $\begin{array}{l}1.949 \\
(1.919)\end{array}$ & $\begin{array}{c}0.057 \\
(0.340)\end{array}$ & $\begin{array}{l}-0.078 \\
(0.631)\end{array}$ \\
\hline Obese & $\begin{array}{c}0.579 \\
(0.573)\end{array}$ & $\begin{array}{l}1.446 \\
(1.167)\end{array}$ & $\begin{array}{c}0.254 \\
(0.167)\end{array}$ & $\begin{array}{c}0.220 \\
(0.269)\end{array}$ \\
\hline $\begin{array}{c}\text { First Stage F-test } \\
\text { Observations }\end{array}$ & $\begin{array}{l}2.621 \\
1,740\end{array}$ & $\begin{array}{l}1.764 \\
1,328\end{array}$ & $\begin{array}{l}12.01 \\
1,913\end{array}$ & $\begin{array}{l}3.385 \\
1,449\end{array}$ \\
\hline \multicolumn{5}{|c|}{ The Impact of Education on Smoking } \\
\hline Ever Smoked & $\begin{array}{l}-0.952 \\
(2.042)\end{array}$ & $\begin{array}{l}-3.828 \\
(4.177)\end{array}$ & $\begin{array}{l}-0.002 \\
(0.274)\end{array}$ & $\begin{array}{c}0.236 \\
(0.409)\end{array}$ \\
\hline Current Smoker & $\begin{array}{c}0.243 \\
(2.101)\end{array}$ & $\begin{array}{l}-2.932 \\
(3.393)\end{array}$ & $\begin{array}{c}0.114 \\
(0.313)\end{array}$ & $\begin{array}{c}0.369 \\
(0.482)\end{array}$ \\
\hline $\begin{array}{c}\text { First Stage F-test } \\
\text { Observations }\end{array}$ & $\begin{array}{l}0.592 \\
1,449\end{array}$ & $\begin{array}{l}0.705 \\
1,122\end{array}$ & $\begin{array}{l}11.03 \\
1,649\end{array}$ & $\begin{array}{l}5.937 \\
1,235\end{array}$ \\
\hline Smokes Every Day & $\begin{array}{l}-5.280 \\
(52.609)\end{array}$ & $\begin{array}{c}3.844 \\
(9.592)\end{array}$ & $\begin{array}{c}0.324 \\
(0.851)\end{array}$ & $\begin{array}{c}1.209 \\
(2.527)\end{array}$ \\
\hline $\begin{array}{l}\text { First Stage F-test } \\
\text { Observations }\end{array}$ & $\begin{array}{c}0.009 \\
744\end{array}$ & $\begin{array}{c}0.187 \\
557\end{array}$ & $\begin{array}{c}2.588 \\
303\end{array}$ & $\begin{array}{c}0.504 \\
231\end{array}$ \\
\hline No. of Cigarettes & $\begin{array}{l}-117.447 \\
(257.098)\end{array}$ & $\begin{array}{c}80.839 \\
(317.341)\end{array}$ & $\begin{array}{c}-15.301 \\
(22.230)\end{array}$ & $\begin{array}{c}-16.052 \\
(55.546)\end{array}$ \\
\hline $\begin{array}{c}\text { First Stage F-test } \\
\text { Observations }\end{array}$ & $\begin{array}{c}0.206 \\
673\end{array}$ & $\begin{array}{c}0.078 \\
505\end{array}$ & $\begin{array}{c}1.891 \\
237\end{array}$ & $\begin{array}{c}0.321 \\
177\end{array}$ \\
\hline
\end{tabular}

Robust standard errors, corrected for clustering on the region by birth cohort, are in parentheses. *, **, and *** indicate statistical significance at the $10 \%, 5 \%$, and $1 \%$ levels, respectively. All models control for the survey year fixed effects, survey region fixed effects, and re-centered birth year in a quadratic form. In columns (1) and (2) the full set of age dummies are controlled for and in columns (3) and (4) age and age squared are whether specified. Reform is $=1$ if birth year $>=1987$, and $=0$ otherwise. Birth cohort of 1986 is excluded from the specifications because they were exposed to the compulsory reform is uncertain. 


\section{Appendix Figure 1}
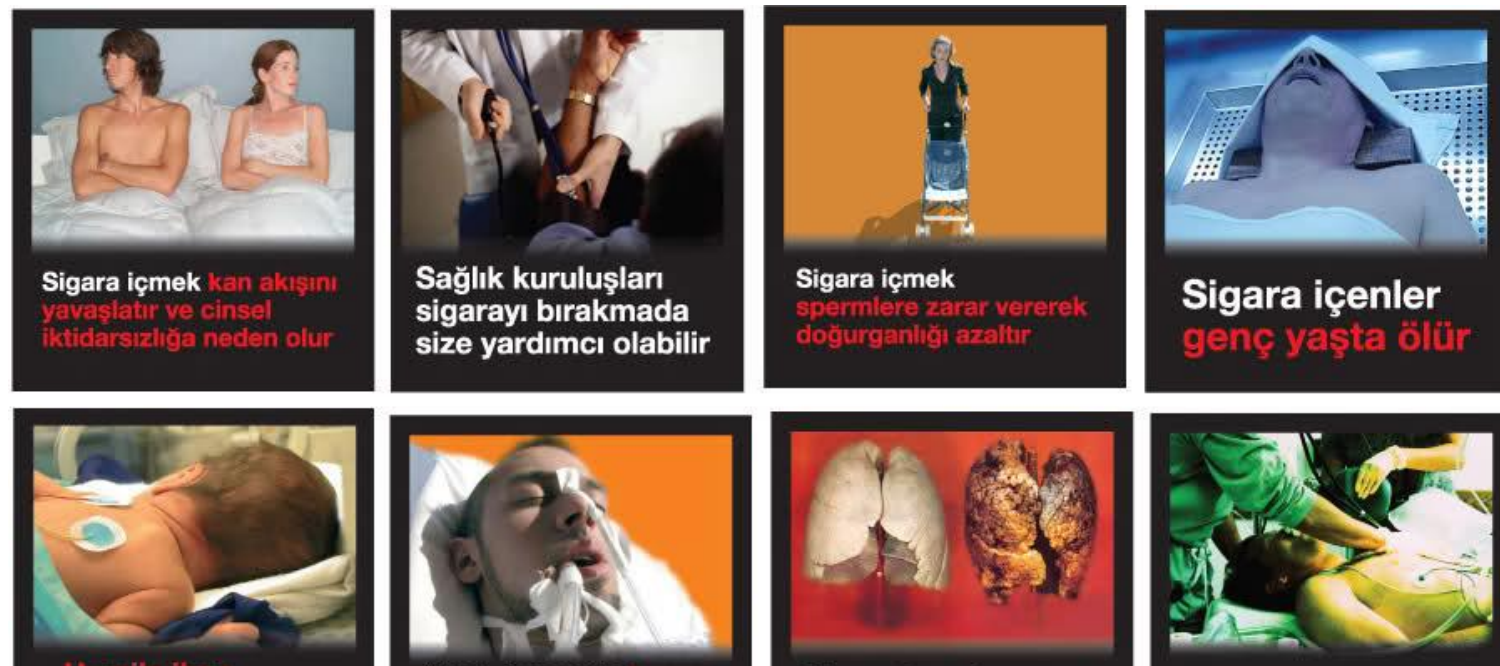

Hamile iken

sigara içmek

bebege zarar verit

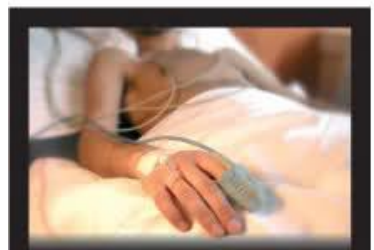

Sigara içmek

agrili ve yavas bir

ölüme neden olabilir
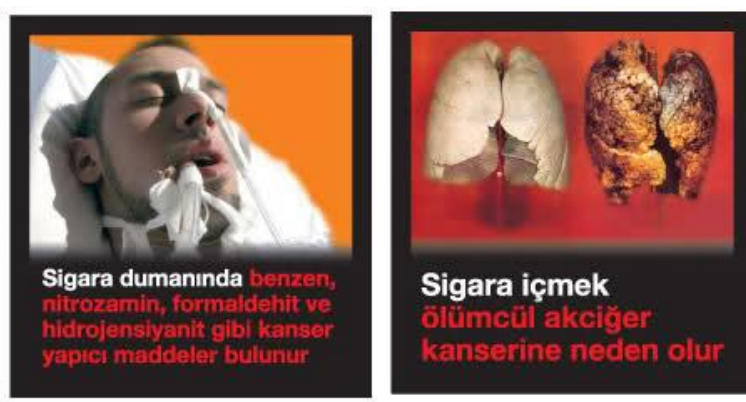

Sigara içmek

ölümeưl akciğer

kanserine neden olur
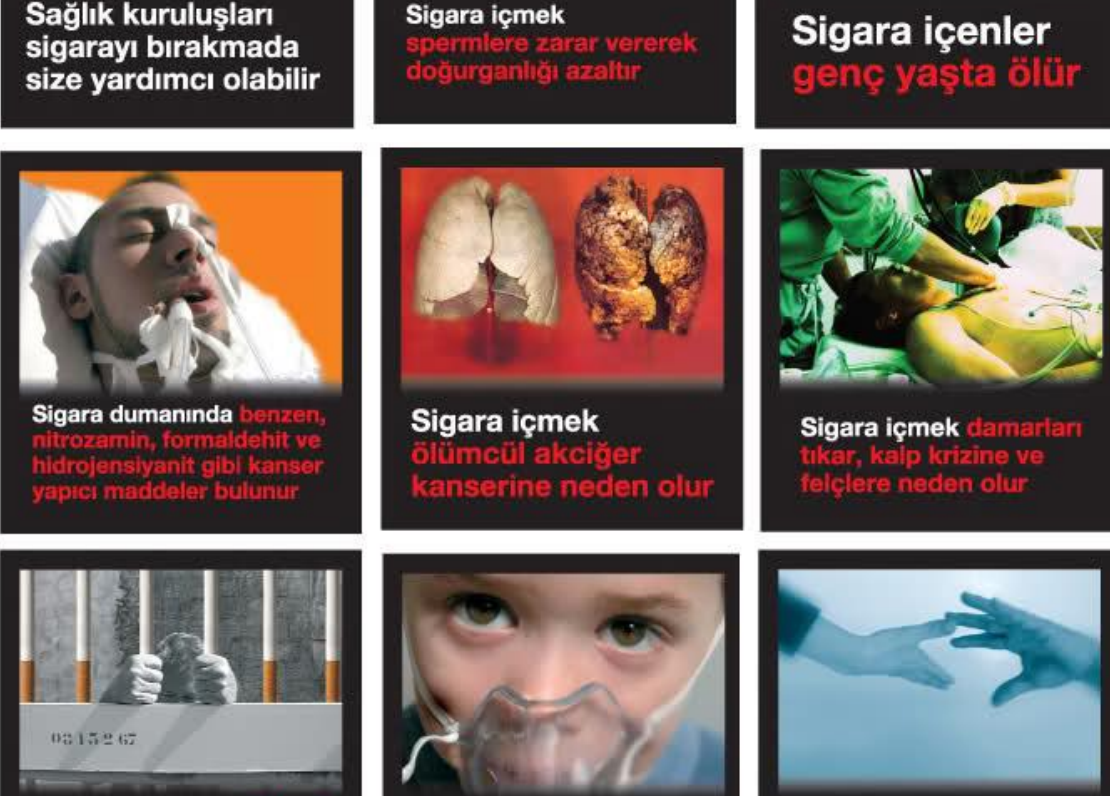

Sigara içmek yüiksek

derecede bağimlilik

yapar, başlamayın
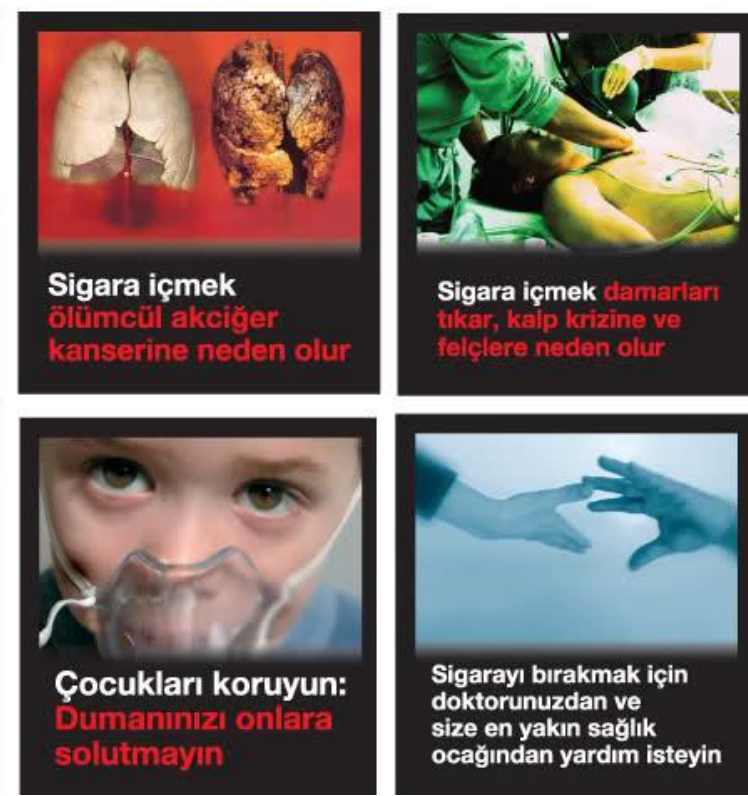

Sigara içmek damariarı

tukar, kalp krizine ve

felçlere neden olur

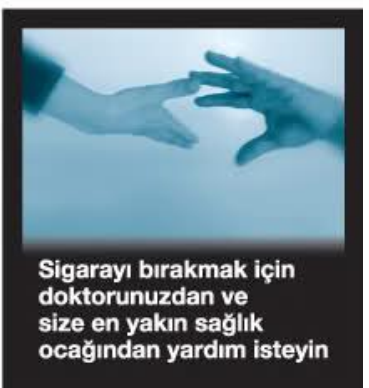

Photo Credit: http://eczanehaber.tv/wp-content/uploads/2013/09/sigara-paketi-uzerindeki-uyariresimleri.jpg. October, 2014.

Top row, from left to right:

1) Smoking reduces blood flow and causes impotence.

2) Health institutions can help you to stop smoking.

3) Smoking can damage the sperm and decreases fertility.

4) Smokers die young.

Second row, from left to right:

5) Smoking when pregnant harms your baby.

6) Smoke contains carcinogenic substances including; benzene, nitrosamines, formaldehyde, hydrogen cyanide.

7) Smoking causes fatal lung cancer.

8) Smoking clogs the arteries and causes heart attacks and strokes.

Bottom row, from left to right:

9) Smoking can cause a slow and painful death.

10) Smoking is highly addictive, don't start.

11) Protect children: Don't make them breathe your smoke.

12) Get help from your doctor or primary health care center to stop smoking. 